\section{OAK RIDGE NATIONAL LABORATORY}

MARTIN MARIETTA

\section{Molten Salt Oxidation of Chloro- Organic Compounds: Experimental Results for Product Gas Compositions and Final Forms Studies}

\author{
J. C. Rudolph \\ P. A. Haas \\ J. T. Bell \\ S. M. Crosley \\ C. L. Calhoun, Jr. \\ A. H. Gorin \\ L. E. Nulf
}


This report has been reproduced directly from the best available copy.

Available to DOE and DOE contractors from the Office of Scientific and Techntcal Information, P.O. Box 62, Oak Ridge, TN 37831; prices available from (615) 576-8401, FTS 626-8401.

Available to the public from the National Technical Information Service, U.S. Department of Commerce, 5285 Port Royal Rd., Springfield, VA 22161.

This report was prepared as an account of work sponsored by an agency of the United States Government. Neither the United States Government nor any agency thereof, nor any of their employees, makes any warranty, express or implied, or assumes any legal liability or responsibility for the accuracy, completeness, or usefulness of any information, apparatus, product, or process disclosed, or represents that its use would not infringe privately owned rights. Reference herein to any specific commercial product, process, or service by trade name, trademark, manufacturer, or otherwise, does not necessarily constitute or imply its endorsement, recommendation, or favoring by the United States Government or any agency thereof. The views and opinions of authors expressed herein do not necessarily state or reflect those of the United States Government or any agency thereof. 


\section{DISCLAIMER}

This report was prepared as an account of work sponsored by an agency of the United States Government. Neither the United States Government nor any agency Thereof, nor any of their employees, makes any warranty, express or implied, or assumes any legal liability or responsibility for the accuracy, completeness, or usefulness of any information, apparatus, product, or process disclosed, or represents that its use would not infringe privately owned rights. Reference herein to any specific commercial product, process, or service by trade name, trademark, manufacturer, or otherwise does not necessarily constitute or imply its endorsement, recommendation, or favoring by the United States Government or any agency thereof. The views and opinions of authors expressed herein do not necessarily state or reflect those of the United States Government or any agency thereof. 


\section{DISCLAIMER}

Portions of this document may be illegible in electronic image products. Images are produced from the best available original document. 
OAK RIDGE NATIONAL LABORATORY

MARTIN MARHETTA

\section{Molten Salt Oxidation of Chloro- Organic Compounds: Experimental Results for Product Gas \\ Compositions and Final Forms Studies}

J. C. Rudolph

P. A. Haas

J. T. Bell

S. M. Crosley

C. L. Calhoun, Jr.

A. H. Gorin

L. E. Nulf 
This report has been reproduced directly from the best available copy.

Available to DOE and DOE contrectors from the Office of Scientfic and Techntcal Intormation, P.O. Box 62, Oak Ridge, TN 37831; prices available trom (615) 576-8401, FTS 626-8401.

Avallable to the public from the National Technical Information Service, U.S. Department of Commerce, 5285 Port Royal Rd., Springfield, VA 22161.

This report was prepared as an account of work eponeored by an agency of the United States Government. Neither the United States Government nor any agency thereof, nor any of their employees, makes any werranty, express or implied, or assumes any legal liability or responsibility for the accuracy, completeness, or usefuiness of any information, apparatus, product, or process disclosed, or represents that its use would not infringe privately owned righte. Reference herein to any epecific commercial product, process, or service by trade name, trademark, manufacturer, or otherwise, does not necesearily constitute or imply its endorsement, recommendation, or favoring by the United States Government or any agency thereof. The views and opinions of authors expressed herein do not necesserily state or reflect those of the United States Government or any agency thereof. 


\section{DISCLAIMER}

Portions of this document may be illegible in electronic image products. Images are produced from the best available original document. 
Chemical Technology Division

\title{
MOLTEN SALT OXIDATION OF CHLORO-ORGANIC COMPOUNDS: EXPERIMENTAL RESULTS FOR PRODUCT GAS COMPOSITIONS AND FINAL FORMS STUDIES
}

\author{
J. C. Rudolph \\ P. A. Haas \\ J. T. Bell \\ S. M. Crosley \\ C. L. Calhoun, Jr. \\ A. H. Gorin \\ L. E. Nulf
}

Date published: April 1995

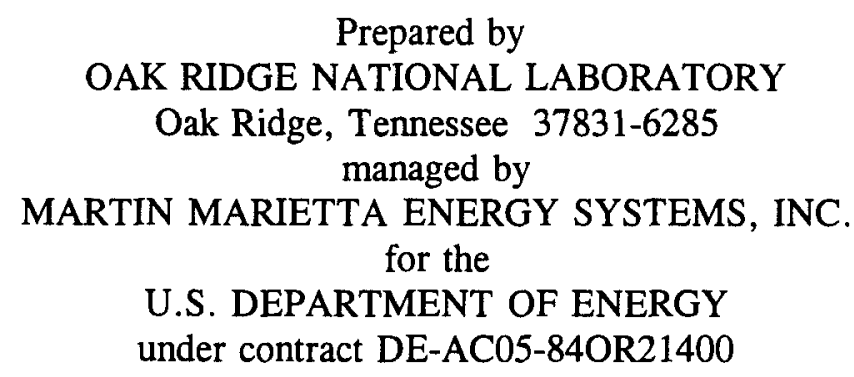




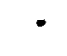




\section{CONTENTS}

LIST OF FIGURES $\ldots \ldots \ldots \ldots \ldots \ldots \ldots \ldots \ldots \ldots \ldots$

LIST OF TABLES $\ldots \ldots \ldots \ldots \ldots \ldots \ldots \ldots \ldots \ldots \ldots \ldots$

EXECUTIVE SUMMARY $\ldots \ldots \ldots \ldots \ldots \ldots \ldots \ldots \ldots \ldots$

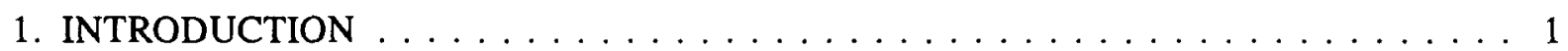

2. DESCRIPTION AND ORIGIN OF MOLTEN SALT OXIDATION OF WASTES $\ldots \ldots \ldots$

3. OBJECTIVES OF THE EXPERIMENTS $\ldots \ldots \ldots \ldots \ldots \ldots$

4. EXPERIMENTAL APPARATUS AND PROCEDURES $\ldots \ldots \ldots \ldots \ldots \ldots$

4.1 EXPERIMENTAL (SPECIFIC FOR OFF-GAS ANALYSIS) $\ldots \ldots \ldots \ldots \ldots \ldots$

4.2 EXPERIMENTAL PROCEDURES (FINAL FORMS) $\ldots \ldots \ldots \ldots \ldots \ldots$

5. METHODS FOR SAMPLING AND ANALYSES $\ldots \ldots \ldots \ldots \ldots$

6. RESULTS FOR DESTRUCTION EFFICIENCIES $\ldots \ldots \ldots \ldots \ldots \ldots \ldots$

7. RESULTS FOR PRODUCTS OF INCOMPLETE COMBUSTION $\ldots \ldots \ldots \ldots$

8. RESULTS FOR DIOXINS AND FURANS $\ldots \ldots \ldots \ldots \ldots \ldots \ldots \ldots$

9. RESULTS FOR FINAL FORMS $\ldots \ldots \ldots \ldots \ldots$

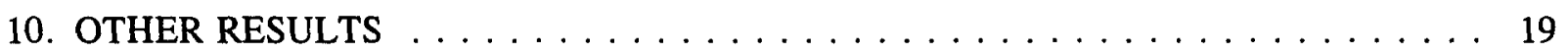

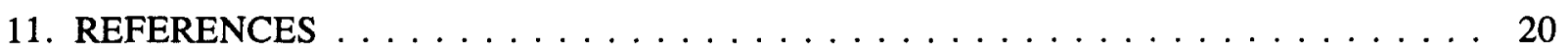

Appendix A. SUBCONTRACT FOR ANALYSES $\ldots \ldots \ldots \ldots \ldots \ldots \ldots$

Appendix B. APPLICATION OF A THERMODYNAMIC COMPUTER

PROGRAM TO MSO REACTIONS ............... 25

Appendix C. "SAMPLING REPORT FOR WASTE STREAM COMBUSTION PRODUCTS FROM A MOLTEN SALT OXIDATION SYSTEM AT OAK RIDGE NATIONAL LABORATORY" (ATTACHMENTS NOT INCLUDED), IT PROJECT NO. $406977 \ldots \ldots \ldots \ldots$. . . . . . . . 31 


\section{LIST OF FIGURES}

Figure $\quad$ Page

1 Schematic diagram of bench-scale MSO apparatus $\ldots \ldots \ldots \ldots \ldots \ldots$

2 TCLP extract concentrations of toxic metals for SPC-immobilized spent salt $\ldots \ldots \ldots$ 


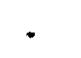




\section{LIST OF TABLES}

Table

Page

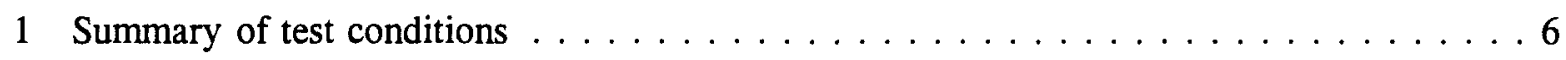

2 Composition of spent-salt mixtures with concentrations of hazardous constituents $\ldots \ldots 8$

3 Destruction and removal efficiencies (DREs) $\ldots \ldots \ldots \ldots$

4 Discharge concentrations of detected organic compounds (corrected to $7 \% \mathrm{O}_{2}$, dry air) . 11

5 Comparison of emission rates (ng/kJ) in MSO bench-scale unit with those of

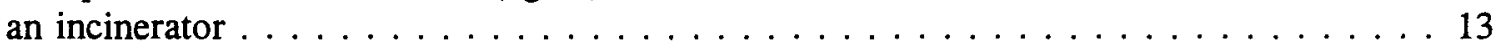

6 Discharge rates of detected organic compounds scaled to 20 - and $100-\mathrm{kg} / \mathrm{h}$ units $\ldots . .14$

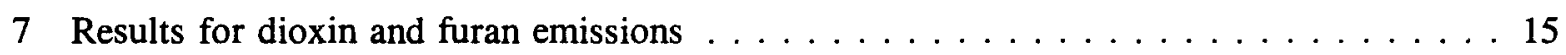

8 TCLP extract concentrations of toxic metals for SPC-immobilized spent salt $\ldots \ldots 17$

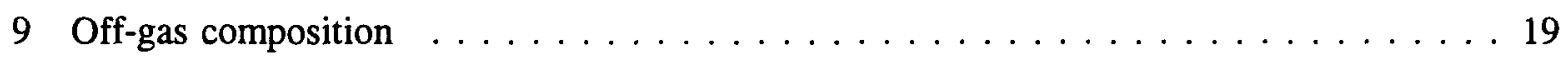

B-1 Some typical equilibrium amounts vs melt and gas compositions . . . . . . . . . . . 29

B-2 Equilibrium compositions and volatilities for small amounts of metals $\ldots \ldots \ldots$ 
.

\section{.}

, 


\section{EXECUTIVE SUMMARY}

The primary objective of the experiments performed was to show that dioxin and furan emissions from a molten salt oxidation (MSO) unit were below the proposed regulatory limit of 0.1 $\mathrm{ng} / \mathrm{m}^{3}$ as 2,3,7,8-tetrachlorodibenzo-para-dioxin equivalents or toxic equivalence quotient. The feed stream was to contain 2,4-dichlorophenol, a suspected precursor to the formation of dioxin and furans. The tests were to be done over a range of salt compositions and flow rates expected in a pilot- or full-scale MSO unit. Two other objectives were to demonstrate destruction and removal efficiencies (DREs) greater than U.S. Environmental Protection Agency requirements and to show that levels of products of incomplete combustion (PICs) are the same as, or lower than, those observed in incinerators for two common waste constituents [carbon tetrachloride $\left(\mathrm{CCl}_{4}\right)$ and $\mathrm{CH}_{3} \mathrm{CCl}_{3}$. The off-gas sampling and analysis was performed by IT Corporation. A final objective was to perform some initial studies of final waste forms using sulfur polymer cement (SPC).

The results show that dioxin formation is minimal $\left(<0.015 \mathrm{ng} / \mathrm{m}^{3}\right)$, at least up to levels of $20 \mathrm{~mol} \%$ chloride content and normal $(0.8-\mathrm{ft} / \mathrm{s})$ gas velocity. The same is true at low chlorine content ( $<5 \mathrm{~mol} \%)$ and high (1.6-ft/s) gas velocity. (No 2,4-dichlorophenol was present in the 20 mol \% $\mathrm{NaCl}$ test at high flow rate; hence, no conclusions can be drawn from this run.) At high sodium chloride concentrations, difficulties with sample extraction at the analytical laboratory led to high detection limits and, in some cases, to no detection capability for certain dioxin isomers. No definitive conclusions can be drawn at these conditions.

Operating at up to $20 \mathrm{~mol} \% \mathrm{NaCl}$ at flow rates under $1.0 \mathrm{ft} / \mathrm{s}$ should provide no difficulties as far as dioxin emissions are concerned, particularly when one considers that the $1.8 \mathrm{wt} \%$ of dioxin precursors is a much higher concentration than one would expect in a typical waste stream. This makes the current conditions proposed for Lawrence Livermore National Laboratory's Mixed Waste Management Facility unit ( $20 \mathrm{~mol} \% \mathrm{NaCl}$ and a $1.0-\mathrm{ft} / \mathrm{s}$ superficial velocity) appear satisfactory with respect to dioxin and furan formation. Furthermore, with no increase in emissions from 0 to $20 \mathrm{~mol} \% \mathrm{NaCl}$ and low concentrations of detectable isomers at $40 \mathrm{~mol} \% \mathrm{NaCl}$, it appears likely that chlorine levels will not affect dioxin emissions appreciably. Obviously, dioxin testing will have to be performed at the pilot scale as well, and the higher chlorine conditions can be retested there.

At least $99.9999+\%$ destruction efficiency was achieved for $\mathrm{CCl}_{4}$ and 1,1,1-trichloroethane (TCA) in every run except test 6 . The sampling tubes that collected the high concentrations of $\mathrm{CCl}_{4}$ and TCA during test 6 were operating at the time that a pressure alarm was tripped. Even with this disturbance, $99.99+\%$ destruction efficiency (the regulatory requirement) was still achieved over the upset period, and $99.999+\%$ DRE was achieved over the entire test period.

No 2,4-dichlorophenol was observed in any of the experiments. The detection limits for the semivolatile compounds were significantly higher than those for the volatile compounds. This unfortunately does not enable us to show $99.9999+\%$ destruction efficiency for this compound. However, the greatest concern with chlorinated phenols is their capability to form dioxins and furans, as previously indicated. The actual destruction of 2,4-dichlorophenol is relatively unimportant.

No effect of $\mathrm{NaCl}$ concentration or airflow rate on the DRE results was observed. Even during test $7(1.6-\mathrm{ft} / \mathrm{s}$ velocity and $40 \mathrm{~mol} \% \mathrm{NaCl})$, where high carbon monoxide (CO) emissions were observed (1600 ppm on average), only a small amount of TCA was observed in one set of tubes. In general, very little, if any, relationship appears to exist between $\mathrm{CO}$ emissions and 
destruction of organic compounds in an MSO system. This was also shown in previous experiments at Oak Ridge National Laboratory, where minimal total hydrocarbon levels were observed at the same time as high $\mathrm{CO}$ emissions.

The only important PICs observed in the tests were chloromethane, methylene chloride, benzene, and toluene. Acetone and methyl ethyl ketone were present in relatively high levels but were found in most of the laboratory blanks as well. All of the concentrations found in tests 1-6 are very low $(<4 \mathrm{ppb})$. Test 7 does show a marked increase in benzene $(27.4 \mathrm{ppb})$, chloromethane $(11$ $\mathrm{ppb})$, and toluene ( $2.6 \mathrm{ppb}$ ) emissions. Even with this increase, the levels are still equal to or below those seen for similar compounds in hazardous waste and municipal incinerators.

Toxicity Characteristic Leaching Procedure tests were performed on 12 salt samples. Six were contaminated with $\mathrm{Ba}$ (and other unregulated metals), and the other six, with $\mathrm{Ba}, \mathrm{Cr}$, and $\mathrm{Cd}$. Barium concentrations were well below Resource Conservation and Recovery Act limits for all tests. For Mix 1, chromium levels were below the limit for $25 \mathrm{wt} \%$ waste loading and for two trials at $35 \mathrm{wt} \%$ but were above the limits for one trial at $35 \mathrm{wt} \%$. For Mix 2, chromium levels were above the limit for $25 \mathrm{wt} \%$ waste loading but were under the limits for $35 \mathrm{wt} \%$ waste loading. Cadmium was not detected during sample characterization in either of the prepared mixes but was detected in the Mix 1 extractants because of experimental or analytical error. Further data on SPC with complexing additives such as $\mathrm{Na}_{2} \mathrm{~S}$ and on other heavy metals such as lead and arsenic should be obtained before this option is either validated or refuted for immobilization of MSO spent salt.

The experiments show that the DREs of the feed constituents and the PICs produced were acceptable at all test conditions. Dioxin and furan emissions were acceptable up to $20 \mathrm{~mol} \% \mathrm{NaCl}$ but are not definitively known at the $40 \mathrm{~mol} \% \mathrm{NaCl}$ concentration as a result of analytical limitations. The elevated $\mathrm{CO}$ release in two of the tests was expected and shows that DREs and PIC formation are not necessarily related to $\mathrm{CO}$ emission.

The primary authors of this study believe that residual organic compounds emitted in the offgas are not a concern at the examined conditions. This opinion is based on the fact that two commonly observed off-gas species ( $\mathrm{CCl}_{4}$ and TCA) and a precursor to dioxin and furan concentration (2,4-dichlorophenol) were fed and destroyed without any significant emissions being observed. Obviously off-gas monitoring should be performed more rigorously on a pilot-scale level, but these bench-scale studies show sufficient evidence of reliable destruction to make further benchscale studies in this area unnecessary. Information of importance that could and should be obtained on a bench-scale level includes the following:

1. volatility/entrainment of radionuclides;

2. expected particle size distributions and concentrations for design of air pollution control devices;

*The large increase in benzene concentration was due to one spike observed in one of four sets of tubes. It was the only compound over this sample period to show this dramatic increase (see IT project no. 406977, Appendix B, test 7, January 1995). One would typically expect an increase in at least closely related PICs such as toluene. Therefore, it is believed that this value may well represent sample contamination and not actual process conditions. 
3. reduction of $\mathrm{CO}$ emissions using catalysts, such as vanadium oxide, either in the molten salt bath or downstream in a catalytic converter (only if it is still deemed necessary despite the fact that $\mathrm{CO}$ emissions do not appear to correlate with organic emissions in a MSO system); and

4. preliminary testing of potential feed streams.

These items would not need to be completed prior to pilot-scale construction but could be done as construction proceeds. 


\section{INTRODUCTION}

Molten salt oxidation (MSO) has been selected as a promising technology for treatment of some U.S. Department of Energy (DOE) mixed wastes. Mixed wastes are defined as those wastes that contain both radioactive components, which are regulated by the Atomic Energy Act of 1954, and hazardous waste components, which are regulated under the Resource Conservation and Recovery Act (RCRA). Oak Ridge National Laboratory (ORNL) has installed and operated a bench-scale MSO apparatus to obtain experimental information needed before the design and construction of an MSO pilot plant.

This report presents the results from operation of the bench-scale MSO system with chlorinated organics in a liquid feed. The destruction efficiencies for these organics and the formation of dioxins and furans were measured using sampling and analytical procedures approved and accepted by the U.S. Environmental Protection Agency (EPA). Composition measurements were also made for the other compositions in the exit gases, the melt samples, and the condensed solids. These studies were planned in cooperation with related studies at Lawrence Livermore National Laboratory (LLNL). The apparatus and operating conditions were those developed and initially tested for MSO studies by Rockwell International Corporation and used for the preliminary MSO experiments at ORNL. ${ }^{1,2}$

\section{DESCRIPTION AND ORIGIN OF MOLTEN SALT OXIDATION OF WASTES}

The MSO process for treatment of wastes is to react the waste and an excess of air by injecting them into a molten salt. The primary salt feed to the melt is sodium carbonate $\left(\mathrm{Na}_{2} \mathrm{CO}_{3}\right)$. The melt will contain $\mathrm{NaCl}, \mathrm{Na}_{2} \mathrm{SO}_{4}$, other sodium salts, and other metal compounds from the reaction products of the waste feed. Other metal carbonates may be added to lower the melting point of the salt.

The molten sodium carbonate has several important characteristics: (1) it is stable, nontoxic, and compatible with the $\mathrm{CO}_{2}$ and $\mathrm{H}_{2} \mathrm{O}$ products; (2) it reacts with acidic products such as $\mathrm{HCl}$ or $\mathrm{Cl}_{2}$ from organic chlorine compounds $\left(\mathrm{SO}_{2}, \mathrm{P}_{2} \mathrm{O}_{5}\right.$, etc.) to form sodium salts that remain in the melt; and (3) it is an excellent heat-transfer medium and heat sink. The sodium carbonate acts as a catalyst or reactant, and the destruction efficiencies for toxic organics are better in molten salt at 900 to $1000^{\circ} \mathrm{C}$ than for simple incineration at the same temperatures. ${ }^{3}$

One important characteristic of MSO as a waste treatment process is its good retention of metals as oxides or salts in the salt residues. The entrained or condensed solids in the cooled offgases are easily collected and discharged as a residue by bag filters. Acid gases react with $\mathrm{Na}_{2} \mathrm{CO}_{3}$ in the melt and are retained as the sodium salts. The MSO treatment results in efficient destruction of waste constituents to yield salt residues and off-gases that can be discharged without scrubbing and without any aqueous scrubber residues.

The efficient collection of metallic salts and ash in the salt residues is both an advantage and limitation for MSO treatment of mixed wastes. The MSO treatment is not suitable for high contents of ash or noncombustible solids in the waste feed; excessive amounts of carbonate salt would be removed as residues in order to remove these solids. High concentrations of elements that form acid gases when wastes are reacted with $\mathrm{O}_{2}\left(\mathrm{Cl}, \mathrm{F}, \mathrm{S}, \mathrm{P}\right.$, etc.) convert large amounts of $\mathrm{Na}_{2} \mathrm{CO}_{3}$ to the 
corresponding sodium salts. The same amounts of sodium salts are formed in the scrubbers for incinerators. Whether the salt residues or the scrubber slurries are preferred for conversion to final waste forms is determined by the processing necessary to prepare these residues for final disposal.

The MSO process for treatment of hazardous wastes was developed by Rockwell International in the 1970 s and 1980s. ${ }^{3-6}$ Molten salt technology was initially developed for other nonwaste applications in nuclear fuel cycles. One of the first tests with radioactive wastes was for solid transuranic wastes. ${ }^{5}$ The MSO treatment was also tested for both liquid and solid chemical wastes. ${ }^{3}$ Destruction efficiencies were determined for chemical warfare agents, pesticides, and a number of toxic chemicals. ${ }^{4}$ At that time, MSO was less developed than conventional incineration, and the advantages of MSO were not important enough to lead to commercial applications.

The inherent MSO advantages of high destruction efficiencies and no aqueous scrubber effluents are important for treatment of mixed wastes. Several assessment studies have concluded that MSO is one of the most promising and the most completely demonstrated alternatives to incineration for mixed wastes. The operation of an MSO bench-scale system at ORNL and an MSO pilot plant at LLNL is part of a DOE program to apply MSO to mixed wastes. The initial ORNL results for carbon monoxide and nitrogen oxide emissions and for metal retentions have been reported. ${ }^{1}$

\section{OBJECTIVES OF THE EXPERIMENTS}

The objectives of the experiments in MSO at the Energy Technology Engineering Center (ETEC), LLNL, and ORNL were to address as many as possible of the primary technical concerns raised by an independent committee, ${ }^{7}$ given the budgetary and time constraints. The primary objective of the ORNL experiments, designated as a potential "show stopper" by the committee, ${ }^{8}$ was to show that the emissions of dioxins and furans were acceptable when a suspected precursor to dioxin and furan formation was injected with the feed. This was to be examined over a range of proposed operating conditions, specifically from 0 to $40 \mathrm{~mol} \%$ sodium chloride concentration and at superficial velocities of 0.8 and $1.6 \mathrm{ft} / \mathrm{s}$ through the reactor.

The proposed limit for dioxin and furan emissions from hazardous waste treatment systems is $0.1 \mathrm{ng} / \mathrm{m}^{3}$ toxic equivalence quotient (TEQ). ${ }^{9}$ The ideal performance goal for these experiments was to show that dioxin and furan concentrations were well below the proposed limits for all conditions examined. An acceptable result would be low emission results over a sufficiently wide range of conditions that practical operational limits could be implemented.

Another goal of the ORNL experiments was to show that destruction and removal efficiencies (DREs) for a few common waste constituents were above EPA standards at the operating conditions previously described, as well as to show that products of incomplete combustion (PICs) are at levels equal to or below those commonly observed in incinerator off-gas streams.

The EPA performance standard for the treatment of hazardous organic constituents is a DRE of $99.99 \%$ by weight, except for those wastes listed as FO20, FO21, FO22, FO23, FO26, and FO27 (wastes with suspected potential to form dioxins and furans), which must meet a DRE of $99.9999 \% .^{10}$ An ideal result would be to show greater than $99.9999 \%$ DRE of each constituent over all conditions, with low amounts of PICs. An adequate result would be to show at least $99.99 \%$ DRE with low PIC levels at the same conditions that showed acceptable dioxin and furan emissions. 
The objective of the final waste form study was to perform development testing of suitable forms for ultimate disposal of spent sodium carbonate/sodium chloride mixtures generated by the MSO process during waste treatment campaigns. With the limited time and funding, it was decided to treat the types of residues that would be expected if no salt recycle were implemented. This was done because processed salt of this type was readily available. Two promising matrix materials for disposal, polyethylene and sulfur polymer cement (SPC), were evaluated. The SPC studies were conducted in laboratories at the Oak Ridge Y-12 Plant, while polyethylene studies were conducted concurrently at LLNL.

\section{EXPERIMENTAL APPARATUS AND PROCEDURES}

The bench-scale apparatus (Fig. 1) consists of a 6-in.-diam, 3-ft-deep alumina crucible that is filled with salt to a depth of 6 to 8 in. (liquid level). This crucible is further contained within an Inconel $600^{\mathrm{TM}}$ vessel as a secondary containment. The feed (waste) material is injected through the top of the vessel and pumped down the inner of two concentric Inconel 600 tubes ( $1 / 4$ in. and $1 / 2$ in., respectively) along with a dispersing gas (either $\mathrm{N}_{2}$ or air). Oxidizing air is fed through the outer tube. These tubes are enclosed in an 1/2-in.-diam alumina pipe termed a "downcomer." The Inconel tubes end $\sim 10 \mathrm{in}$. from the crucible bottom (above the level of the stagnant salt), and the downcomer carries the feed and gases into the salt. (It extends to within 1 in. of the crucible bottom.) The offgases from the oxidation process pass through a knockout drum, where condensed and entrained particles are collected. The gases then proceed through a prefilter and a high-efficiency particulate air (HEPA) filter before entering the plant stack ventilation system.

The controlled variables in the system are the furnace temperatures, feed material, feed rate, air and dispersing gas rates and pressures, dispersing gas composition $\left(\mathrm{N}_{2}\right.$ or air), and salt composition. Instrumentation is installed to measure and record the salt bath and other temperatures, various pressures, and analyses of off-gas compositions (for a gas sample taken after the prefilter). Measurements of the destruction efficiencies for the organics in the feed and of the formation of dioxins and furans required special sampling and analytical procedures by a subcontractor (see Sect. 5 and Appendix A).

The installed instrumentation analyzes for five off-gas compositions: oxygen $\left(\mathrm{O}_{2}\right)$, carbon monoxide $(\mathrm{CO})$, carbon dioxide $\left(\mathrm{CO}_{2}\right)$, hydrocarbons $(\mathrm{HCs})$, and $\mathrm{NO}_{x}$. The oxygen and $\mathrm{CO}_{2}$ measurements are taken primarily to allow a mass balance on the overall system. The $\mathrm{CO}$ measurements are taken to determine both the oxidation potential of the system as well as the typical $\mathrm{CO}$ concentrations that can be expected under various conditions. There will be $\mathrm{CO}$ and $\mathrm{NO}_{x}$ concentration limitations for the off-gas of a waste treatment plant. The HC analyzer shows whether relatively large quantities of unreacted organic material $(>5 \mathrm{ppm}$ ) escape reaction. This measurement is not precise enough for determining the DREs for the organic waste. The $\mathrm{O}_{2}$ is detected by its paramagnetism. The $\mathrm{CO}$ and $\mathrm{CO}_{2}$ analyzers both detect the characteristic infrared spectra of these gases. The $\mathrm{HC}$ analyzer works on the principle of flame ionization of the hydrocarbon by hydrogen in a blanket of air. The $\mathrm{NO}_{x}$ analyzer functions by first converting all of the $\mathrm{NO}_{x}$ to $\mathrm{NO}$ and then passing the sample into a chamber with ozone, where the following reaction occurs:

$$
\mathrm{NO}+\mathrm{O}_{3} \rightarrow \mathrm{NO}_{2}+\mathrm{O}_{2}+\mathrm{h}_{v}
$$




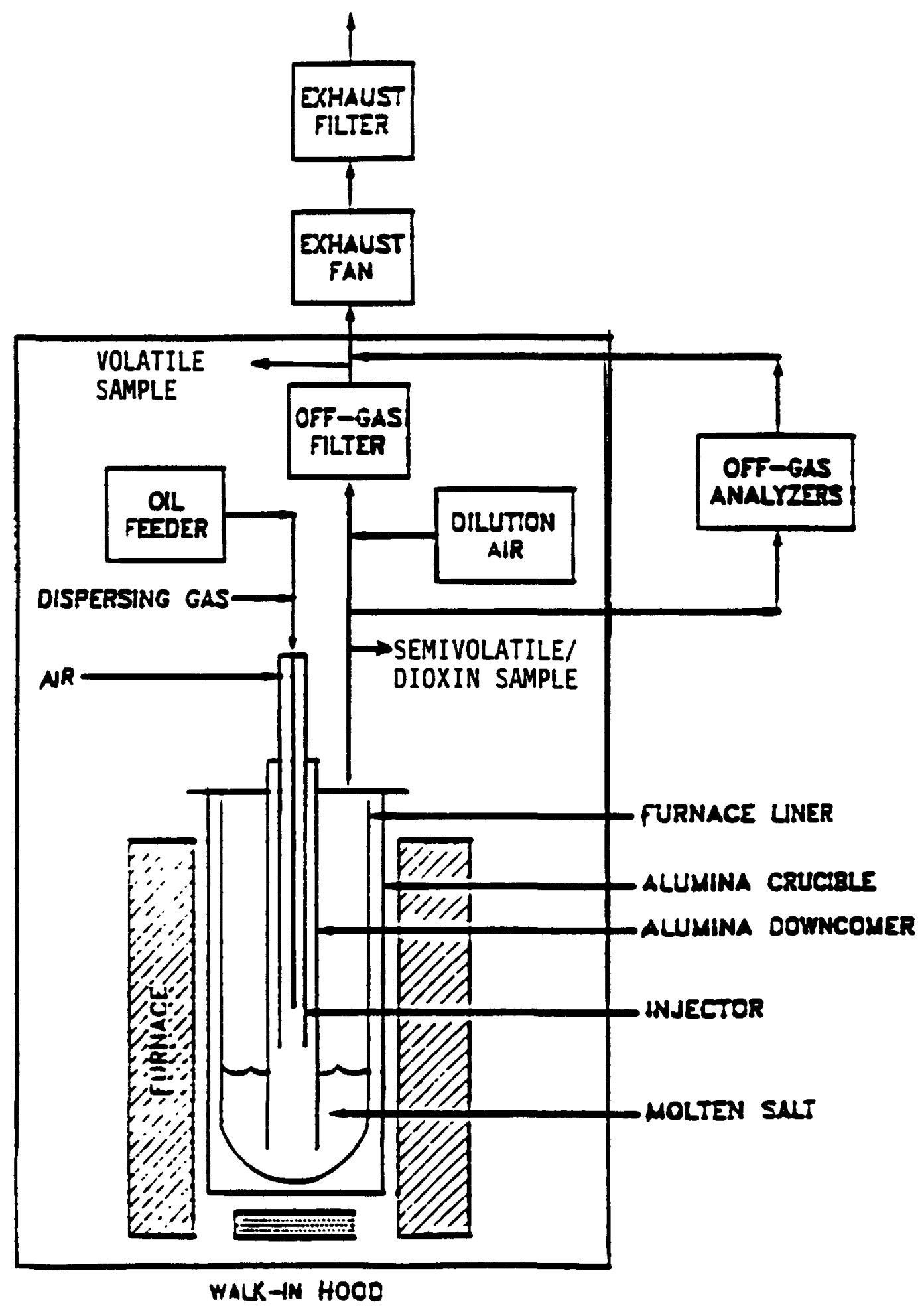

Fig. 1. Schematic diagram of bench-scale MSO apparatus. 
The intensity of light emitted by the de-excitation of the $\mathrm{NO}_{2}$ molecules provides an accurate measure of the $\mathrm{NO}_{x}$ concentration.

The instrumentation for off-gas analyses was calibrated before each test using three standard gas mixtures and pure air or nitrogen from cylinders to set the zero and span values.

\subsection{EXPERIMENTAL (SPECIFIC FOR OFF-GAS ANALYSIS)}

The surrogate compounds used in the experiments were carbon tetrachloride $\left(\mathrm{CCl}_{4}\right)$, 1,1,1-trichloroethane (TCA), and 2,4-dichlorophenol. The first two are common RCRA solvents in wastes, and the last, with the structure shown below, is considered a strong precursor to dioxins and furans:<smiles>Oc1ccc(Cl)cc1Cl</smiles>

Chlorinated aromatics, phenols in particular, are suspected to have the highest potential for dioxin formation; the more highly chlorinated the aromatic is, the higher the potential. The compound 2,4-dichlorophenol was chosen for the ORNL experiments because of its relatively low melting point $\left(45^{\circ} \mathrm{C}\right)$, which would help in forming the feed solution. Two of the most toxic varieties of dioxins and furans-2,3,7,8-tetrachlorodibenzo-para-dioxin (2,3,7,8-TCDD) and 2,3,4,7,8-pentachlorodibenzofuran (2,3,4,7,8-PeCDF)-are shown below:<smiles>Clc1cc2c(cc1Cl)Oc1cc(Cl)c(Cl)cc1O2</smiles>

$2,3,7,8-\mathrm{TCDD}$<smiles>Clc1cc2oc3c(Cl)c(Cl)c(Cl)cc3c2cc1Cl</smiles>

$2,3,4,7,8-\mathrm{PeCDF}$

The surrogates were fed in diluent streams composed primarily of ethylene glycol with $\approx 10$ wt \% ethanol for miscibility (as indicated in the following discussion). The $\mathrm{CCl}_{4}$ and $\mathrm{TCA}$ were fed at concentrations of 3.6-3.7 wt \% in each test except the first. During the first experiment, it was discovered that two phases were present in the feed liquid. The test compounds were not completely miscible in pure ethylene glycol (the only diluent in test 1 ) at these concentrations. As a result, the remaining feed solution from test 1 had to be analyzed; the concentration fed was then backcalculated. Ethanol was added in all subsequent tests to combine the two phases, and the problem was not encountered again. The 2,4-dichlorophenol was typically run at $1.8 \mathrm{wt} \%$, but runs with twice this concentration (test 3 ) and with no dichlorophenol (test 6) were run as well to see if any significant change in species was detected in the off-gas. Table 1 shows operating conditions for each test. Test 4 was a background sample of laboratory air for dioxin and furan analysis. Because test 4 was not an actual run on the molten salt reactor, results from this test do not appear in data tables. For results of test 4, see Appendix C, Table 5-6. 
Table 1. Summary of test conditions"

\begin{tabular}{|c|c|c|c|c|c|c|c|c|c|c|c|c|c|c|c|c|}
\hline \multirow[b]{3}{*}{ Test } & \multirow{3}{*}{$\begin{array}{c}\text { Feed } \\
\text { flow } \\
\text { (g/nnin) }\end{array}$} & \multirow{3}{*}{$\begin{array}{l}\text { Aırflow } \\
\text { (L/mın, } \\
\text { at STP) }\end{array}$} & \multirow{3}{*}{$\begin{array}{c}\text { Superficial } \\
\text { velocity } \\
(\mathrm{cm} / \mathrm{s})\end{array}$} & \multicolumn{4}{|c|}{ Feed composition $\left(w 1 x_{0}\right)^{b}$} & \multirow{3}{*}{$\begin{array}{c}\text { Excess } \\
\text { air } \\
(\%)\end{array}$} & \multirow{3}{*}{$\begin{array}{c}\text { Run } \\
\text { length } \\
\text { (h:min) }\end{array}$} & \multirow{3}{*}{$\begin{array}{l}\text { Melt } \\
\text { temp. } \\
\left({ }^{\circ} \mathrm{C}\right)\end{array}$} & \multicolumn{6}{|c|}{$\mathrm{NaCl}$ content (mol \%) } \\
\hline & & & & \multirow{2}{*}{$\mathrm{CCl}_{4}{ }^{\circ}$} & \multirow{2}{*}{$\mathrm{TCA}^{d}$} & \multirow{2}{*}{ Phenol $^{*}$} & \multirow{2}{*}{ EIOIY' } & & & & \multicolumn{2}{|c|}{ Initial } & \multicolumn{2}{|c|}{ Final } & \multicolumn{2}{|c|}{ Average } \\
\hline & & & & & & & & & & & Meas.' & Calc. & Meas. & Calc. & Meas. & Calc \\
\hline 1 & 665 & 481 & 247 & 428 & 430 & 121 & $\mathbf{0} \mathbf{0 0}$ & 81 & $4: 05$ & 949 & 2.33 & 2.33 & 680 & 808 & 457 & 521 \\
\hline 2 & 687 & 484 & 249 & 3.68 & 3.63 & 182 & 928 & 65 & 4.09 & 948 & 18.8 & 19.9 & 25.4 & 244 & 221 & 222 \\
\hline 3 & 706 & 484 & 250 & 3.68 & 3.67 & 365 & 9.38 & 60 & 3:00 & 949 & 402 & 40.2 & 43.3 & 432 & 418 & 417 \\
\hline 6 & 13.93 & 988 & 510 & 3.68 & 364 & 000 & 9.30 & 66 & $3: 47$ & 951 & 21.3 & 21.2 & 287 & 284 & 250 & 248 \\
\hline 7 & 14.29 & 968 & 50.2 & 3.68 & 3.66 & 182 & 9.35 & 58 & $3: 33$ & 951 & 44.3 & 41.0 & 47.1 & 472 & 457 & 441 \\
\hline
\end{tabular}

Test 4, which was a background sample, is omitted from all tables. Results for test 4 are found in Appendix C, Table 5-6.

${ }^{6}$ Remainder of feed is ethylene glycol.

' $\mathrm{CCl}$, is carbon tetrachloride.

TCA is 1,1,1-trichloroethane.

'Phenol is 2,4-dichlorophenol.

EtOH is ethanol

Initial measurements of $\mathrm{NaCl}$ concentration were taken prior to the nun. The calculated amount of chlorine added before attainment of steady state has been included in each of these values. 
The initial salt charge was $6.62 \mathrm{~kg}$ of sodium carbonate $\left(\mathrm{Na}_{2} \mathrm{CO}_{3}\right)$. After test 3 the salt was removed and a fresh charge of $6.62 \mathrm{~kg}$ of $\mathrm{Na}_{2} \mathrm{CO}_{3}$ was added. Air was used as the diluent gas in all tests.

The night prior to each test, the furnace was set to keep the salt at approximately $900^{\circ} \mathrm{C}$. In tests $2,3,6$, and 7 , either pure $\mathrm{CCl}_{4}$ or TCA was fed to raise the chlorine content of the melt up to the required mole percent for that test. (Tests 1 and 5 began near $0 \mathrm{~mol} \mathrm{\%} \mathrm{NaCl}$.) Ethylene glycol was then fed to raise the salt temperature to $950^{\circ} \mathrm{C}$ without increasing the chlorine content of the melt. When the temperature stabilized near $950^{\circ} \mathrm{C}$, the ethylene glycol was discontinued and the test feed was started. Generally the feed ran for approximately 20 to $30 \mathrm{~min}$ before steady state was achieved. After steady state was achieved, personnel from IT Corporation began sampling the gas streams. Sample lines for volatile and semivolatile/dioxin measurements were attached as shown in Fig. 1. The semivolatile/dioxin sampling was done prior to passing the off-gas through filters, where dioxins adhering to particulates could be trapped, and was performed at a sufficiently low temperature $\left(<270^{\circ} \mathrm{C}\right)$ that there was little chance of any dioxin formation downstream of the sampling location. Steady state was maintained as long as necessary to obtain reliable dioxin and furan measurements. This period of time was determined by IT personnel.

Salt samples were taken before and after each run and were then sent for analysis. Since feed solution typically was injected for 20 or 30 min prior to sampling, the chlorine added over this time had to be added to the measured beginning concentration to obtain the initial $\mathrm{NaCl}$ concentration at the time sampling commenced. The airflow in tests 1-3 was set such that superficial velocity through the salt was approximately $0.8 \mathrm{ft} / \mathrm{s}$. This is approximately the value of the design velocity identified in LLNL's Conceptual Design Report. ${ }^{11}$ Tests 5-7 were run at $1.6 \mathrm{ft} / \mathrm{s}$ to check the effects of residence time.

The typical pressure in the reactor was 2 to 3 in. of $\mathrm{H}_{2} \mathrm{O}$. The pressure would slowly rise to 5 or 6 in. and, if allowed, would increase rapidly after reaching $6 \mathrm{in}$. Whenever the pressure increased to $5 \mathrm{in}$., the pipe directly exiting the reactor was mechanically rodded out to reduce the pressure to its original level. The chlorine concentration had a large effect on the frequency of these rod-outs and is discussed in Sect. 10.

A pinch point was encountered when rodding out the exiting pipe that would momentarily raise the reactor pressure to 20 or 30 in. or higher. In test 6 this caused a pressure alarm to trip and shut off the fuel flows and airflows. It is believed that this process allowed feed dispersed in the injection tube to coalesce. When the air was restarted, a slug of feed was then forced into the reactor and did not have a chance to completely react. This affected DREs for that period and is discussed in Sect. 6.

\subsection{EXPERIMENTAL PROCEDURES (FINAL FORMS)}

Two compositions of spent salt from MSO bench-scale reactor tests were selected for encapsulation in SPC only. Previous work has demonstrated that the addition of additives to SPC batches-including $\mathrm{Na}_{2} \mathrm{~S}, \mathrm{Al}_{2} \mathrm{O}_{3}$, and $\mathrm{Fe}_{2} \mathrm{O}_{3}$-may enhance final form performance. Due to the technical and time constraints of the program and the untimely shutdown of the laboratories at the

Oak Ridge Y-12 Plant, these additives were not incorporated into the experimental matrix. The approximate compositions of the tested mixtures are given in Table 2. 
Table 2. Composition of spent-salt mixtures with concentrations of hazardous constituents

\begin{tabular}{lcc}
\hline Constituent & $\begin{array}{c}\text { Mix } 1: 20 \mathrm{~mol} \% \mathrm{NaCl} / 80 \mathrm{~mol} \% \\
\mathrm{Na}_{2} \mathrm{CO}_{3}(\mathrm{ppm})\end{array}$ & $\begin{array}{c}\text { Mix 2: } \\
\% \mathrm{~mol}_{2} \% \mathrm{NaCl} / 55 \mathrm{~mol} \\
\mathrm{Na}_{2}(\mathrm{ppm})\end{array}$ \\
$\mathrm{Ba}$ & 1,800 & 5,400 \\
$\mathrm{Cs}$ & 880 & $\mathrm{NA}^{a}$ \\
$\mathrm{Ce}$ & $<37$ & $\mathrm{NA}$ \\
$\mathrm{Sr}$ & 1,300 & $\mathrm{NA}$ \\
$\mathrm{Co}$ & 400 & $\mathrm{NA}$ \\
$\mathrm{Cl}$ & 73,000 & 190,000 \\
$\mathrm{Na}$ & 430,000 & $\mathrm{NA}$ \\
$\mathrm{CO}_{3}{ }^{2-}$ & 500,000 & $\mathrm{NA}$ \\
$\mathrm{Cd}^{-}$ & $\mathrm{NA}$ & 57 \\
$\mathrm{Cr}$ & $\mathrm{NA}$ & 6,100 \\
\hline
\end{tabular}

${ }^{a} \mathrm{NA}=$ not analyzed.

The spent salt, as received, consisted of irregularly shaped nuggets ranging up to several centimeters in diameter. Each mixture was ground by mortar and pestle to less than $2.36 \mathrm{~mm}$. These two compositions of spent salt (Mix 1 and Mix 2) were utilized, and two waste loadings (25 wt \% and $35 \mathrm{wt} \%$ ) were selected. Three samples of each salt composition at each waste loading were made as described in the following discussion, yielding a total of 12 specimens.

SPC was premelted in a stainless steel reaction vessel at $135^{\circ} \mathrm{C}$ in an open air environment. Next, the waste composition was slowly added, and the mixture was stirred at $\sim 10$-min intervals during the course of the run. Each run was maintained at $135^{\circ} \mathrm{C}$ for $2 \mathrm{~h}$ and subsequently allowed to "slow cool" to room temperature. The resulting monolith was then crushed and passed through a 9.5-mm screen for Toxicity Characteristic Leaching Procedure (TCLP) extraction and analysis.

\section{METHODS FOR SAMPLING AND ANALYSES}

A requirement for selection of the sampling and analysis procedures was that they meet all EPA requirements for demonstrating compliance by a waste treatment facility. The application to our experiments did not include all the blanks and quality assurance procedures that would be used for a operating waste facility. These analytical services were provided by a subcontract with IT Corporation (312 Directors Drive, Knoxville, Tennessee 37923). A description of the sampling and analysis procedures may be found in Appendix C, Sect. 4. 


\section{RESULTS FOR DESTRUCTION EFFICIENCIES}

Since MSO is proposed strictly for treating high-organic-content waste streams, DREs are one of the main criteria for judging the effectiveness of this treatment option. Multiple studies of the capability of a molten salt, typically sodium carbonate $\left(\mathrm{Na}_{2} \mathrm{CO}_{3}\right)$, to achieve these DREs for various compounds have been published by Rockwell International. ${ }^{3,4,12}$ More recently, ETEC published a report detailing the DREs and products of incomplete combustion (PICs) from the treatment of 50 gal of waste oil that was contaminated with very low levels of radioactivity and spiked with trichloroethylene (TCE). ${ }^{2}$ Although all of the DREs published showed very high levels of destruction, only the ETEC report goes into detail about PICs. According to Clyde Newman (program manager at ETEC), the technical review committee had some concerns about the amount of phenol detected in the off-gas system. ${ }^{13}$ Although only a small amount was detected, the concern was that phenols are suspected precursors of polychlorinated dioxins and furans.

The ORNL experiments examined two common DOE waste constituents with high chlorine content, as well as one compound that has high potential to form dioxins and furans. These compounds were treated over a range of $\mathrm{NaCl}$ concentrations that have been proposed as practical limits of operation, namely, $0-40 \mathrm{~mol} \% \mathrm{NaCl}$ in $\mathrm{Na}_{2} \mathrm{CO}_{3}$. The effect of $\mathrm{NaCl}$ on DREs and PICs has not been well quantified in the past. In addition, the effect of gas velocity (i.e., residence time), a key parameter in thermal treatment, was also examined.

The sampling of the off-gas is described in Appendix C, Sect. 3.0. Both $\mathrm{CCl}_{4}$ and TCA are classified as volatile organic compounds, which are sampled using the volatile organic sampling technique (VOST) procedure (see Appendix C, Table 3-2). As described in Appendix C, Table 3-2, three or four sets of tubes are used for each test and each set is individually analyzed. In most cases, $\mathrm{CCl}_{4}$ or TCA would show up at very low levels in only one of the sets of tubes.

A summary of the results can be found in Table 3. Levels of $\mathrm{CCl}_{4}$ and TCA observed are shown in Table 4 and in Appendix C, Table 5-1. The key to Table 3 explains in detail the maximum and minimum DRE values. At least $99.9999+\%$ destruction efficiency was achieved for $\mathrm{CCl}_{4}$ and TCA in every run except test 6 . The sampling tubes that collected the high concentration of $\mathrm{CCl}_{4}$ and TCA during test 6 were operating at the time the pressure alarm was tripped (see Sect. 4.1). Even with this disturbance, $99.99+\%$ destruction efficiency (the regulatory requirement) was still achieved over the upset period and $99.999+\%$ DRE was achieved over the test period.

No 2,4-dichlorophenol was observed in any of the experiments. However, the detection limits for the semivolatile compounds were significantly higher than those for the volatile compounds. This unfortunately does not enable us to show $99.9999+\%$ destruction efficiency for this compound. However, the greatest concern with chlorinated phenols is their capability of forming dioxins and furans; these results are given in Sect. 8. Test 6 was the run that contained no 2,4-dichlorophenol; consequently, no DRE is listed.

No effect of $\mathrm{NaCl}$ concentration or airflow rate on the DRE results was observed. Even during test 7, where high carbon monoxide (CO) emissions were observed (1600 ppm on average), only a small amount of TCA was observed in one set of tubes. In general, very little, if any, relationship appears to exist between $\mathrm{CO}$ emissions and destruction of organic compounds in an MSO system. This finding was also noted in previous experiments at ORNL, where minimal total HC levels were observed at the same time as high $\mathrm{CO}$ emissions.' 
Table 3. Destruction and removal efficiencies (DREs)

\begin{tabular}{|c|c|c|c|c|c|c|c|c|}
\hline & \multicolumn{8}{|c|}{ Test } \\
\hline & 1 & 2 & 3 & 5 & $6 \mathrm{~A}^{\circ}$ & $6 \mathrm{~B}^{4}$ & $6 \mathrm{C}^{\circ}$ & 7 \\
\hline \multicolumn{9}{|l|}{ Conc., ng/L } \\
\hline $\mathrm{CCl}_{4}, b$ inlet & $5.20 E+06$ & $4.57 \mathrm{E}+06$ & $4.68 \mathrm{E}+06$ & $3.89 \mathrm{E}+06$ & $4.54 \mathrm{E}+06$ & $4.54 \mathrm{E}+06$ & $4.54 \mathrm{E}+06$ & $4.74 E+06$ \\
\hline TCA, inlet & $5.22 \mathrm{E}+06$ & $4.50 \mathrm{E}+06$ & $4.67 E+06$ & $3.85 \mathrm{E}+06$ & $4.49 \mathrm{E}+06$ & $4.49 \mathrm{E}+06$ & $4.49 E+06$ & $4.71 E+06$ \\
\hline $\mathrm{CCl}_{4}$, outlet $\min ^{d}$ & 0.00 & 1.22 & 0.33 & 0.00 & 12.50 & 0.00 & 37.50 & 0.00 \\
\hline TCA, outlet min & 0.00 & 0.00 & 0.18 & 0.21 & 16.50 & 0.00 & 49.50 & 0.21 \\
\hline $\mathrm{CCl}_{4}$, outlet max & $0.5, u^{e}$ & 1.55 & 0.58 & $0.5, \mathrm{u}$ & 12.80 & $0.5, \mathrm{u}$ & 37.50 & $0.5, \mathrm{U}$ \\
\hline TCA, outlet max & $0.5, \mathrm{U}$ & $0.5, \mathrm{U}$ & 0.55 & 0.59 & 16.80 & $0.5, \mathrm{U}$ & 49.50 & 0.59 \\
\hline \multicolumn{9}{|l|}{ DRE, $\%$} \\
\hline $\mathrm{CCl}_{4}, \min$ & 99.999992 & 99.999971 & 99.999990 & 99.999988 & 99.999763 & 99.999989 & 99.999174 & 99.999991 \\
\hline TCA, $\min$ & 99.999992 & 99.999990 & 99.999990 & 99.999985 & 99.999686 & 99.999989 & 99.998898 & 99.999990 \\
\hline $\mathrm{CCl}_{4}, \max$ & 100.000000 & 99.999973 & 99.999993 & 100.000000 & 99.999725 & 100.000000 & 99.999174 & 100.000000 \\
\hline TCA, max & 100.000000 & 100.000000 & 99.999996 & 99.9999995 & 99.999633 & 100.000000 & 99.998898 & 99.999995 \\
\hline Phenol,' min & $99.999828^{\circ}$ & 99.999888 & 99.99993 & 99.998283 & $\mathrm{NA}^{*}$ & NA & NA & 99.998734 \\
\hline
\end{tabular}

$8 \mathrm{~A}=$ test 6 with upset; $6 \mathrm{~B}=$ test 6 without upset; $6 \mathrm{C}=$ upset period only. During test 6 , a pressure alarm was activaled, and it shut off both the feed flows and airflows briefly before the pressure was relieved. Airflows and feed flows were then restarted. During the upset period, high values of $\mathrm{CCl}_{4}$ and TCA were observed in the off-gas. It had been noted previously that high peaks of $\mathrm{CO}$ can occur during startup and shutdown. It is believed that this is what caused $\mathrm{CCl}_{4}$ and TCA releases as well.

${ }^{\circ} \mathrm{CCl}_{4}$ is carbon tetrachloride.

TCA is 1,1,1-trichloroethane.

The reason there are minima and maxima placed on the outlet concentrations and DREs for each run is that three or four sets of volatile organic sample technique (VOST) tubes were taken each run. The amount detected from each of these runs was added to obtain the average outlet concentration. The minimum outlet concentrations (maximum DREs) were the amounts actually detected. The maximum outlet concentrations (minimum DREs) are the sum of the detection limit (10 ng) from the runs where no $\mathrm{CCl}_{4}$ or TCA was detected and the amounts that were detected. Typically, these substances were detected in only one set of sampling tubes.

' $\mathrm{U}$ means the substance was not detected in any of the sampling tubes.

'Phenol is 2,4-dichlorophenol.

'No 2,4-dichlorophenol was found in any of the tests. The listed values are the detection limits for this compound.

"NA $=$ not applicable. 
Table 4. Discharge concentrations of detected organic compounds (corrected to $7 \% \mathbf{O}_{2}$, dry air)

\begin{tabular}{|c|c|c|c|c|c|c|c|c|c|c|c|c|}
\hline \multirow[b]{2}{*}{ Compound } & \multicolumn{2}{|c|}{ Test 1} & \multicolumn{2}{|c|}{ Test 2} & \multicolumn{2}{|c|}{ Test 3} & \multicolumn{2}{|c|}{ Test 5} & \multicolumn{2}{|c|}{ Test 6} & \multicolumn{2}{|c|}{ Test 7} \\
\hline & $\mu \mathrm{g} / \mathrm{m}^{3}$ & $\mathrm{ppb}$ & $\mu \mathrm{g} / \mathrm{m}^{3}$ & ppb & $\mu \mathrm{g} / \mathrm{m}^{3}$ & $\mathrm{ppb}$ & $\mu \mathrm{g} / \mathrm{m}^{3}$ & ppb & $\mu \mathrm{g} / \mathrm{m}^{3}$ & ppb & $\mu \mathrm{g} / \mathrm{m}^{3}$ & ppb \\
\hline Chloromethane & $\mathrm{ND}^{a}$ & ND & ND & ND & 0.65 & 0.52 & 0.88 & 0.72 & 2.4 & 1.9 & 14 & 11 \\
\hline Methylene chloride & 1.7 & 1.4 & 1.2 & 0.97 & 1.0 & 0.82 & 1.5 & 1.3 & 1.2 & 0.97 & 0.95 & 0.77 \\
\hline 1,1,1-trichloroethane & ND & ND & ND & ND & 0.52 & 0.42 & 0.70 & 0.57 & 16 & 13 & 0.52 & 0.42 \\
\hline Carbon tetrachloride & ND & ND & 1.5 & 1.2 & 0.54 & 0.44 & ND & ND & 12 & 9.8 & ND & ND \\
\hline Benzene & 0.84 & 0.68 & 3.3 & 2.7 & 3.3 & 2.7 & ND & ND & 0.85 & 0.67 & $33^{b} / 1.5^{c}$ & $27^{b} / 1.2^{c}$ \\
\hline Toluene & ND & ND & 0.66 & 0.53 & 0.65 & 0.52 & 0.70 & 0.57 & 0.61 & 0.49 & 3.2 & 2.6 \\
\hline$n$-Butyle phthalate & 0.29 & 0.24 & ND & ND & 0.72 & 0.58 & ND & ND & ND & ND & ND & ND \\
\hline
\end{tabular}

${ }^{a} \mathrm{ND}=$ not detected.

'The benzene concentration exceeded the calibration range for one set of sample tubes. The listed value is the high-end calibration point, so the actual value may be higher. It is also believed this is due to contamination of the sample rather than being representative of actual process conditions (see p. 16).

'Value for benzene emissions, omitting the suspect set of tubes. 


\section{RESULTS FOR PRODUCTS OF INCOMPLETE COMBUSTION}

In addition to analyzing the off-gas for the feed compounds, a search was made for a standard library of common volatile and semivolatile PICs. Several compounds were detected in only one of the tests at very low levels and were discounted as being insignificant. (None of these were RCRA substances.) Of the compounds detected, the following were detected in more than one sample: chloromethane $\left(\mathrm{CH}_{3} \mathrm{Cl}\right)$; methylene chloride $\left(\mathrm{CH}_{2} \mathrm{Cl}_{2}\right) ; 1$,1,1-trichloroethane $\left(\mathrm{CH}_{3} \mathrm{CCl}_{3}\right)$, which is a feed compound; carbon tetrachloride $\left(\mathrm{CCl}_{4}\right)$, which is a feed compound; benzene $\left(\mathrm{C}_{6} \mathrm{H}_{6}\right)$; toluene $\left(\mathrm{C}_{6} \mathrm{H}_{5} \mathrm{CH}_{3}\right)$; acetone $\left(\mathrm{CH}_{3} \mathrm{COCH}_{3}\right)$; 2-butanone $\left(\mathrm{CH}_{3} \mathrm{COC}_{2} \mathrm{H}_{5}\right)$; benzyl alcohol $\left(\mathrm{C}_{6} \mathrm{H}_{5} \mathrm{CH}_{2} \mathrm{OH}\right)$; 2methylphenol $\left(\mathrm{C}_{6} \mathrm{H}_{4} \mathrm{CH}_{3} \mathrm{OH}\right)$; 4-methylphenol $\left(\mathrm{C}_{6} \mathrm{H}_{4} \mathrm{CH}_{3} \mathrm{OH}\right)$; $n$-butyl phthalate $\left[\mathrm{C}_{6} \mathrm{H}_{4}\left(\mathrm{CO}_{2} \mathrm{C}_{4} \mathrm{H}_{9}\right)_{2}\right]$; and bis(2-ethylhexyl) phthalate $\left(\mathrm{C}_{24} \mathrm{H}_{38} \mathrm{O}_{4}\right)$.

Of these, only chloromethane, toluene, and $n$-butyl phthalate were not also found in at least $50 \%$ of the blanks. Table 4 gives the discharge concentrations for each of these compounds. (Complete emission data can be found in Appendix $C$ to this report, Tables 5-1 and 5-2, and in the report itself (IT project no. 406977), Attachments B and D, January 1995. With the exception of concentrations of $\mathrm{CCl}_{4}$ and TCA in test 6, which have been explained in Sect. 6, all of the concentrations in tests 1-6 are very low $(<4 \mathrm{ppb})$. Test 7 does show a marked increase in benzene, chloromethane, and toluene emissions. Even with this increase, the levels are still equal to or below those seen for similar compounds in hazardous waste and municipal incinerators. ${ }^{14}$ A comparison of emission rates, based on heat content of fuel burned, is shown in Table 5.

Table 6 shows the emission concentrations scaled up to proposed pilot and plant operating capacities. The scale-up calculations were done on the basis that all variables remained constant except for the feed rate. Although this is a much oversimplified method of scaleup, it provides a rough first guess. The estimate is conservative with respect to residence time in the reactor because in larger (pilot- and plant-scale) reactors the superficial velocity of the gases should remain under 2 $\mathrm{ft} / \mathrm{s}$ to keep salt entrainment to a minimum while the salt depth will increase by a factor of approximately four to six. (This calculation assumes a 24-in.-diam vessel and an equivalent melt depth/vessel diameter ratio.) The test temperature of $950^{\circ} \mathrm{C}$ is on the upper end of the range for the MSO process, and lower temperatures should be examined. The pilot-scale calculations are based on the proposed feed rate for the MSO unit planned as part of LLNL's Mixed Waste Management Facility (MWMF).

\section{RESULTS FOR DIOXIN AND FURANS}

Dioxin and furan emissions of a thermal system are subject to extreme scrutiny by both the public and the scientific community. Dioxins and furans, in the context of emissions, are a group of closely related compounds, dibenzo-para-dioxins and dibenzofurans. The highly chlorinated varieties (four or more chlorine atoms per molecule) are the ones suspected of having harmful effects

${ }^{*}$ The large increase in benzene concentration was due to one spike observed in one of four sets of tubes. It was the only compound over this sample period to show this dramatic increase (see IT project no. 406977, Appendix B, test 7, January 1995). One would typically expect an increase in at least closely related PICs such as toluene. Therefore, it is believed that this value may well represent sample contamination and not actual process conditions. 
Table 5. Comparison of emission rates (ng/kJ) in MSO bench-scale unit with those of an incinerator

\begin{tabular}{|c|c|c|c|c|c|c|c|c|}
\hline \multirow[b]{2}{*}{ Compound } & \multicolumn{2}{|c|}{ Incinerator ${ }^{b}$} & \multicolumn{6}{|c|}{ MSO bench-scale test } \\
\hline & Av & Range & 1 & 2 & 3 & 5 & 6 & 7 \\
\hline Chloromethane & $\mathbf{N A}^{c}$ & NA & $\mathrm{ND}^{d}$ & ND & 0.27 & 0.41 & 1.00 & 5.83 \\
\hline Methylene chloride & 2.2 & $0-9.6$ & 0.72 & 0.50 & 0.43 & 0.73 & 0.50 & 0.39 \\
\hline 1,1,1-trichloroethane & 0.3 & $0-1.3$ & ND & ND & 0.22 & 0.33 & 6.72 & 0.39 \\
\hline Carbon tetrachloride & 0.8 & $0.3-1.5$ & ND & 0.63 & 0.23 & $\mathrm{ND}$ & 5.12 & ND \\
\hline Benzene & 87 & $2-980$ & 0.33 & 1.38 & 1.39 & ND & 0.35 & $13.7^{e} / 1.5^{f}$ \\
\hline Toluene & 1.6 & $1.5-4.1$ & ND & 0.27 & 0.29 & 0.33 & 0.25 & 1.32 \\
\hline$n$-Butyl phthalate & NA & NA & 0.12 & ND & 0.30 & ND & ND & ND \\
\hline
\end{tabular}

${ }^{a}$ Nanograms of compound emitted per kilojoule of combustor heat input.

${ }^{b}$ C. R. Dempsey and E. T. Opplet, "Incineration of Hazardous Waste: A Critical Review Update," J. Air Waste Manage. Assoc. 43, 48-49 (1993).

$\mathrm{NA}=$ not available.

${ }^{d} \mathrm{ND}=$ not detected.

The benzene concentration exceeded the calibration range for one set of sample tubes. The value listed is the high-end calibration point, so the actual value may be higher. It is also believed this is due to contamination of the sample rather than being representative of actual process conditions (see p. 16).

fValue for benzene emissions, omitting the suspect set of tubes.

in humans because tests have shown that 2,3,7,8-TCDD can produce cancer and other toxic effects in laboratory animals at very low doses. ${ }^{14}$ No definitive evidence has yet been obtained to verify similar effects in humans. However, the effects in laboratory animals have generated enough concern that the EPA is proposing an emission limit of $0.1 \mathrm{ng} / \mathrm{m}^{3} \mathrm{TEQ}$. The toxic equivalence factor (TEF) of a particular dioxin or furan is listed as a fraction of that for 2,3,7,8-TCDD, which has a TEF of 1. Only the $2,3,7,8$ isomers are considered to be toxicologically significant; therefore, these are the only individual compounds measured. The concentration of each individual dioxin and furan is multiplied by its TEF, and they are then all summed to obtain the total TEQ concentration of the gas. ${ }^{9}$ This value is corrected for a specific oxygen concentration in the air so that dilution cannot be employed as a method of controlling emission levels.

The results from the test are given in Table 7 . The results are not corrected to $11 \% \mathrm{O}_{2}$, which is the suggested value. ${ }^{15}$ However, since $\mathrm{O}_{2}$ levels were below $11 \%$ in all tests (as will be shown in Sect. 10), the emission results can be expected to be lower. The results show that there were recordable levels of dioxins present in each of the six tests. However, the highest detected amount was less than $0.003 \mathrm{ng} / \mathrm{m}^{3} \mathrm{TEQ}$, which is well below the proposed regulatory limit. No 2,3,7,8-TCDD was present in any of the runs. The detection limit concentrations (the TEQ concentration if all compounds are present at their detection limits) were very low for tests $1,2,5$ and $6\left(<0.015 \mathrm{ng} / \mathrm{m}^{3} \mathrm{TEQ}\right)$. However, the analytical laboratory had difficulties in recovering the samples from tests 3 and 7 [refer to the complete IT report (IT project no. 406977), Attachment I, 
Table 6. Discharge rates of detected organic compounds scaled to $20-$ and $100-\mathrm{kg} / \mathrm{h}$ units

\begin{tabular}{|c|c|c|c|c|c|c|c|c|c|c|c|c|}
\hline \multirow[b]{2}{*}{ Compound } & \multicolumn{2}{|c|}{ Test $1(\mathrm{mg} / \mathrm{h})$} & \multicolumn{2}{|c|}{ Test $2(\mathrm{mg} / \mathrm{h})$} & \multicolumn{2}{|c|}{ Test $3(\mathrm{mg} / \mathrm{h})$} & \multicolumn{2}{|c|}{ Test 5 (mg/h) } & \multicolumn{2}{|c|}{ Test $6(\mathrm{mg} / \mathrm{h})$} & \multicolumn{2}{|c|}{ Test $7(\mathrm{mg} / \mathrm{h})$} \\
\hline & Pilot ${ }^{a}$ & Plant & Pilot & Plant & Pilot & Plant & Pilot & Plant & Pilot & Plant & Pilot & Plant \\
\hline Chloromethane & $\mathrm{ND}^{c}$ & ND & ND & ND & 0.098 & 0.49 & 0.24 & 1.2 & 0.71 & 3.5 & 4.3 & 21 \\
\hline Methylene chloride & 0.24 & 1.2 & 0.18 & 0.88 & 0.15 & 0.77 & 0.42 & 2.1 & 0.36 & 1.8 & 0.29 & 1.4 \\
\hline 1,1,1-trichloroethane & ND & ND & ND & ND & 0.078 & 0.39 & 0.19 & 0.95 & 4.8 & 24 & 0.16 & 0.79 \\
\hline Carbon tetrachloride & ND & ND & 0.22 & 1.1 & 0.082 & 0.41 & ND & ND & 3.7 & 18 & ND & ND \\
\hline Benzene & 0.12 & 0.59 & 0.49 & 2.4 & 0.50 & 2.5 & ND & ND & 0.25 & 1.3 & $10^{d} / 0.45^{e}$ & $50^{d} / 0.36^{e}$ \\
\hline Toluene & ND & ND & 0.096 & 0.48 & 0.098 & 0.49 & 0.19 & 0.95 & 0.18 & 0.90 & 0.96 & 4.8 \\
\hline$n$-Butyl phthalate & 0.042 & 0.21 & ND & ND & 0.10 & 0.51 & ND & ND & ND & ND & ND & ND \\
\hline
\end{tabular}

'Pilot unit is assumed to operate at a feed rate of $20 \mathrm{~kg} / \mathrm{h}$.

${ }^{b}$ Plant unit is assumed to operate at a feed rate of $100 \mathrm{~kg} / \mathrm{h}$.

${ }^{\mathrm{C}} \mathrm{ND}=$ not detected.

The benzene concentration exceeded the calibration range for one set of sample tubes. The listed value is the high-end calibration point, so the actual value may be higher. It is also believed this is due to contamination of the sample rather than being representative of actual process conditions (see p. 16).

Value for benzene emissions, omitting the suspect set of tubes. 
Table 7. Results for dioxin and furan emissions

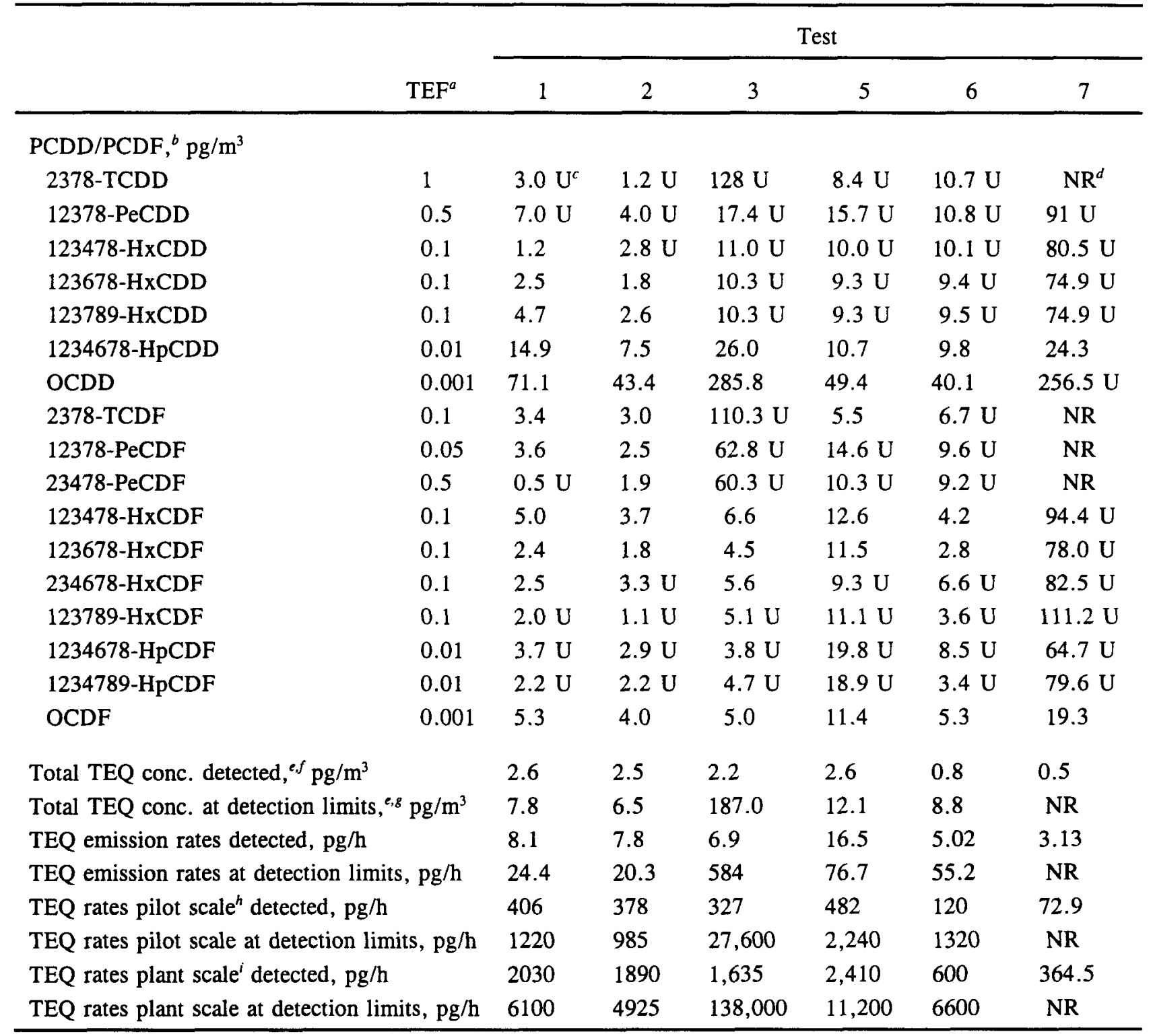

${ }^{\circ} \mathrm{TEF}$ is the toxicity equivalence factor for each of the compounds.

${ }^{\circ} \mathrm{PCDD}$ and PCDF are polychlorinated dibenzodioxins and dibenzofurans, respectively. The compounds listed below are the important toxic compounds.

' $\mathrm{U}$ next to a number indicates that the compound was under detection limits; the listed value is the detection limit. ${ }^{d} \mathrm{NR}$ indicates that no result was given due to complications with analysis.

Values are not corrected for oxygen content.

Total TEQ conc. detected gives the toxicity equivalence concentration released if only the detected compounds are present.

${ }^{8}$ Total TEQ conc. at detection limits gives the toxicity equivalence concentration released if all the compounds are present at detection limits.

${ }^{h}$ Pilot scale is assumed to be $20 \mathrm{~kg} / \mathrm{h}$, the proposed rate for chlorinated compounds at LLNL's MWMF unit.

${ }^{i}$ Plant scale is assumed to be $100 \mathrm{~kg} / \mathrm{h}$. 
January 1995, for more details]. This difficulty led to a detection limit in test 3 of $0.187 \mathrm{ng} / \mathrm{m}^{3} \mathrm{TEQ}$, which is higher than the $0.1-\mathrm{ng} / \mathrm{m}^{3}$ limit. In test 7 there was $0 \%$ recovery of several of the compounds; therefore, an overall TEQ could not be determined. This difficulty had not been previously encountered by the IT personnel, but the suspected cause, a water layer between two hydrophobic materials (the XAD sorbent and the toluene rinse), could be avoided in the future by different recovery techniques.

The results show that dioxin formation is minimal at least up to $20 \mathrm{~mol} \%$ chloride content and normal gas flow rates. The same is true at low chlorine contents $(<5 \mathrm{~mol} \%)$ at high flow rates. (Because no 2,4-dichlorophenol was present in the $20 \mathrm{~mol} \%$ test at high gas flow rate, no conclusions can be drawn from this run.) Therefore, operating at up to $20 \mathrm{~mol} \% \mathrm{NaCl}$ at normal flow rates should provide no difficulties as far as dioxin emissions are concerned. These are the current conditions proposed for LLNL's MWMF unit. Further, with no increase observed from Test 1 to Test 2, it appears likely that chlorine levels will not affect dioxin emissions appreciably. Obviously, dioxin testing will have to be performed at the pilot scale as well, and the higher chlorine conditions can be retested there.

\section{RESULTS FOR FINAL FORMS}

Inductively coupled plasma (ICP) analysis of the TCLP extracts was conducted to determine the effectiveness of SPC as an immobilization agent for MSO spent salt. The concentrations of hazardous metal constituents in the extract were compared with the EPA threshold limits for solid wastes that exhibit the characteristic of toxicity. The relevant limits are as follows:

\begin{tabular}{|c|c|c|}
\hline $\begin{array}{l}\text { EPA hazardous } \\
\text { waste number }\end{array}$ & Contaminant & $\begin{array}{c}\text { Regulatory } \\
\text { level (mg/L) }\end{array}$ \\
\hline D005 & Barium & 100.0 \\
\hline D006 & Cadmium & 1.0 \\
\hline D007 & Chromium & 5.0 \\
\hline
\end{tabular}

The results indicate that SPC was highly successful in the immobilization of all hazardous contaminants for 8 of the 12 MSO runs. Also, at least one hazardous constituent (barium) was sufficiently immobilized to a concentration below regulatory level by SPC in the remaining four trials. Table 8 contains the TCLP extract concentrations of toxic metals for each specimen.

The trials of Mix 1, $35 \mathrm{wt} \%$. exhibited detectable levels of cadmium and chromium. even though neither was added to Mix 1 . There was potential for chromium contamination of the salt from the corrosion of the Inconel $600^{\mathrm{TM}}$ injector, but these concentrations would be much lower $(<100$ $\mathrm{ppm}$ ) than those for Mix 2. Contamination of the salt with cadmium is very unlikely because it is not present in any of the materials used and was not even in the laboratory. Since the Mix 1, $35 \mathrm{wt}$ $\%$, runs were conducted on the same day as the start of the Mix 2 trials, some cross-contamination of equipment may have occurred. However, given the order in which the runs were conducted and the standard procedures employed by the SPC laboratory, this conclusion would appear unlikely. It is also possible that the discrepancy may be the result of an analytical error of the ICP analysis since a large number of different elements were present in the salt. 
Table 8. TCLP extract concentrations of toxic metals for $\mathrm{SPC}^{a}$-immobilized spent salt

\begin{tabular}{ccccc} 
& & \multicolumn{3}{c}{ Concentration (ppm) } \\
\cline { 3 - 5 } Mix 1: 25 wt \% & 1 & $\mathrm{Ba}$ & $\mathrm{Cr}$ & $\mathrm{Cd}$ \\
& 2 & 18.8 & $\mathrm{U}^{a}$ & $\mathrm{U}$ \\
& 3 & 22.3 & $\mathrm{U}$ & $\mathrm{U}$ \\
Mix 1: 35 wt \% & 1 & 17.4 & $\mathrm{U}$ & $\mathrm{U}$ \\
& 2 & 14.7 & 5.8 & 3.8 \\
& 3 & 15.3 & 1.5 & 0.11 \\
Mix 2: 25 wt $\%$ & 1 & 14.1 & 2.9 & $\mathrm{U}$ \\
& 2 & $\mathrm{U}$ & 7.6 & $\mathrm{U}$ \\
& 3 & 12.2 & 7.1 & $\mathrm{U}$ \\
Mix 2: 35 wt \% & 1 & 11.0 & 7.4 & $\mathrm{U}$ \\
& 2 & 15.1 & 4.2 & $\mathrm{U}$ \\
& 3 & $\mathrm{U}$ & 2.6 & $\mathrm{U}$ \\
\hline
\end{tabular}

Interestingly, a significant reduction in the barium concentration for Mix 1 and the chromium concentration for Mix 2 was observed when the loading level was increased. This trend is illustrated by the corresponding chart of TCLP extract concentration in Fig. 2. Since it has been previously demonstrated that sodium can improve the leaching resistance of SPC, it is not too surprising that this trend occurs for higher loadings of spent salt.

It is important to note that these tests were performed on unseparated salt samples. If the salts were dissolved, most of the barium (as $\mathrm{BaCO}_{3}$, Appendix $\mathrm{B}$ ) and almost all of the cadmium (as $\mathrm{CdO}$, Appendix B) would precipitate as insoluble ash, which would be vitrified. Chromium would be soluble (as $\mathrm{Na}_{2} \mathrm{CrO}_{4}$, Appendix $\mathrm{B}$ ). If one supposes that an ash precipitation and separation of carbonate/chloride (and other anions such as fluorides, sulfates, and phosphates) are successful, then the chloride waste stream will be nearly identical to an off-gas scrubber slurry from an incinerator. Therefore, for comparison purposes, what is really necessary is an evaluation of the salt-recycling system.

These results clearly indicate a significant degree of immobilization for toxic metal constituents for both mixtures, and continued development of SPC processing could potentially lead to an enhanced final waste form. However, further data on SPC with complexing additives such as $\mathrm{Na}_{2} \mathrm{~S}$ and on other heavy metals such as lead and arsenic should be obtained before this option is either validated or refuted for immobilization of MSO spent salt. 


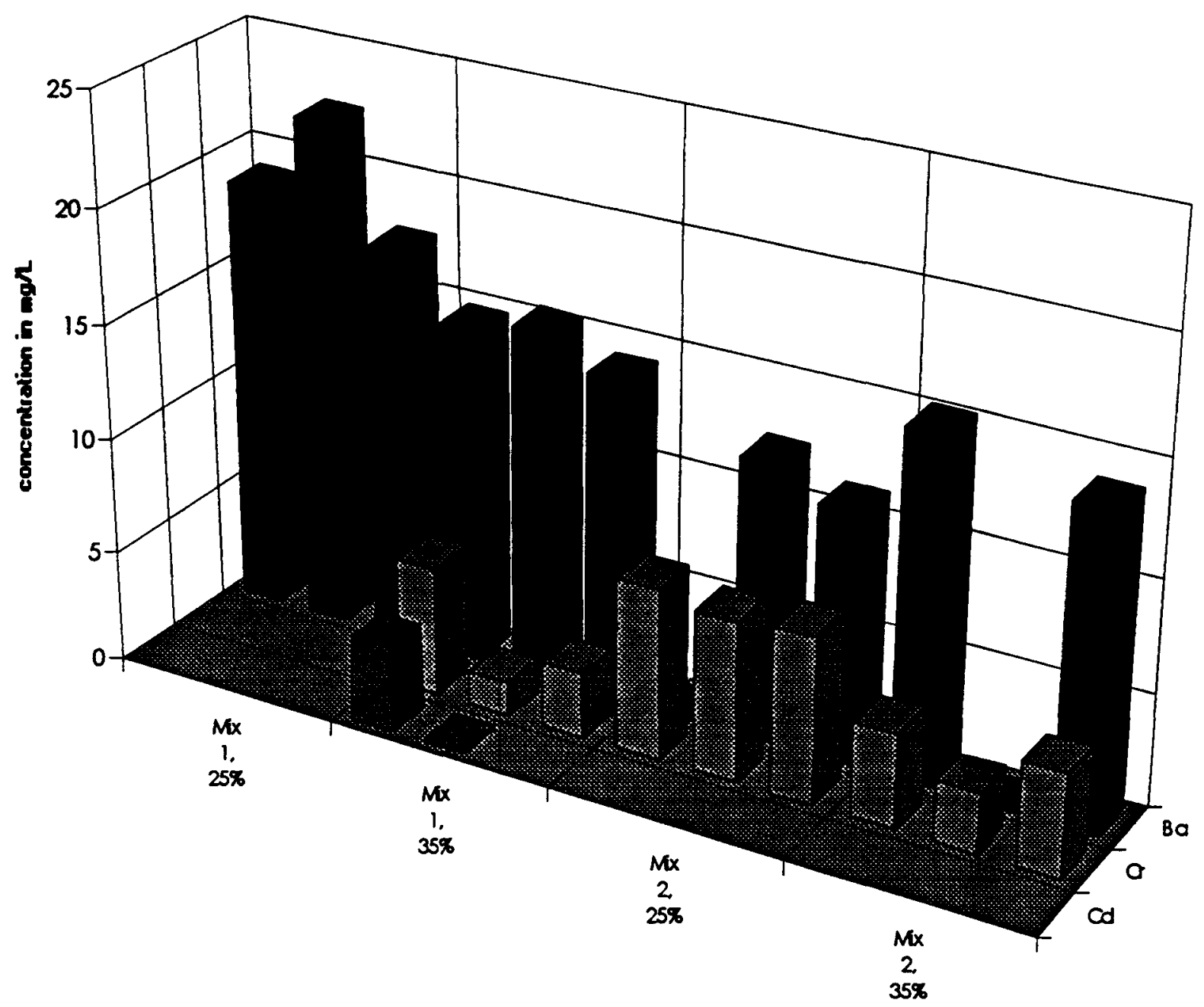

Fig. 2. TCLP extract concentrations of toxic metals for SPC-immobilized spent salt. 


\section{OTHER RESULTS}

In addition to testing the off-gas for organic content, the standard measurements of $\mathrm{CO}, \mathrm{NO}_{x}$, $\mathrm{CO}_{2}$, and $\mathrm{O}_{2}$ were taken as well. Table 9 lists this information as well as the theoretical oxygen and carbon dioxide concentrations for comparison. As found in previous tests at ORNL, ${ }^{1} \mathrm{NO}_{x}$ emissions are below $10 \mathrm{ppm}$ at steady state when no organic nitrogen is present in the feed. Emissions of CO, especially at high $\mathrm{NaCl}$ concentrations, were below what was anticipated from previous data. This phenomenon has been attributed to the much lower excess air concentration and is one of six trends observed in CO emissions in ORNL's previous experiments. ${ }^{1}$ This is a very advantageous result and should be investigated as a means of controlling $\mathrm{CO}$ emissions. The change in flow rate shows a dramatic effect on $\mathrm{CO}$ release and is evidence that the increased residence time in a pilot- or plantscale reactor may decrease $\mathrm{CO}$ emissions significantly.

One significant qualitative observation of the experiments is that sodium chloride volatility has a much greater effect on salt carryover than does entrainment of the salt. A much larger volume of particulate was collected in the off-gas system for the high-chloride-content, low-gas-velocity runs than was collected for the low-chloride-content, high-gas-velocity runs. This finding also indicates that the $\mathrm{NaCl}$ concentration in the gas does not reach equilibrium; otherwise, the carryover would be twice as great. The larger volume of salt increased the frequency of rod-outs of the off-gas system necessary to relieve reactor pressure.

Table 9. Off-gas composition

\begin{tabular}{lllllll}
\hline & \multicolumn{7}{c}{ Test } \\
\cline { 2 - 7 } Compound & 1 & 2 & 3 & 5 & 6 & 7 \\
\hline $\mathrm{CO}, \mathrm{ppm}$ & 30 & 0 & 0 & 0 & 540 & 1600 \\
$\mathrm{NO}_{x}, \mathrm{ppm}$ & 7.1 & 6.9 & 8.7 & 5.8 & 8.5 & 9.0 \\
$\mathrm{CO}_{2}$ (measured), \% & 9.56 & 10.22 & 10.73 & 8.93 & 9.91 & 10.60 \\
$\mathrm{O}_{2}$ (measured), \% & 9.12 & 8.45 & 7.89 & 9.92 & 8.35 & 7.79 \\
$\mathrm{CO}_{2}$ (calculated), \% & 9.75 & 10.46 & 10.80 & 8.70 & 10.33 & 10.87 \\
$\mathrm{O}_{2}$ (calculated), \% & 9.39 & 8.27 & 7.94 & 10.34 & 8.34 & 7.76 \\
\hline
\end{tabular}




\section{REFERENCES}

1. P. A. Haas, J. C. Rudolph, and J. T. Bell, Molten Salt Oxidation of Mixed Wastes: Preliminary Bench-Scale Experiments Without Radioactivity, ORNL/TM-12765, Oak Ridge National Laboratory, Oak Ridge, Tenn., June 1994.

2. A. Darnell et al., Final Report: Molten Salt Oxidation of RMOF Mixed Wastes, 022-TR-0002, Energy Technology Engineering Center of Rockwell International, Canoga Park, Calif. (limited distribution).

3. S. J. Yosim et al., "Molten Salt Destruction of Hazardous Wastes Produced in the Laboratory," pp. 617-632 in Safe Handling of Chemical Carcinogens, Mutagens, Teratogens, and Highly Toxic Substances, Vol. 2, ed. D. B. Waters, Ann Arbor Science, Ann Arbor, Mich., 1979.

4. S. J. Yosim et al., "Disposal of Hazardous Waste by Molten Salt Combustion", pp. 227-241 in Toxic and Hazardous Waste Disposal, Vol. 4, ed. R. J. Pojasek, Ann Arbor Science, Ann Arbor, Mich., 1980.

5. D. E. McKenzie et al., "Mass Reduction of Solid Transuranic Waste by Molten Salt Combustion," AIChE Symp. Ser. 71 (154), 69-75 (1976).

6. R. L. Gay et al., "Fuel Production from Wastes Using Molten Salts," ACS Symp. Ser. 130, 227-236 (1980).

7. J. J. Cudahy et al., Technical Review of Molten Salt Oxidation, prepared for the U.S. Department of Energy, Office of Environmental Management, December 1993.

8. J. J. Cudahy et al., Technical Review of Molten Salt Oxidation, prepared for the U.S. Department of Energy, Office of Environmental Management, December 1993, p. 41.

9. P. Acharya et al., "Factors That Can Influence and Control the Emissions of Dioxins and Furans from Hazardous Waste Incinerators," J. Air Waste Manage. Assoc. 41, 1605-1606 (December 1991).

10. 40 CFR Ch. 1, 264.342 and 264.343, July 1991.

11. J. M. Bowers, Mixed Waste Management Facility Conceptual Design Report, Appendix B: Design Requirements, UCRL-PROP-116761, App B L-17293-1, Lawrence Livermore National Laboratory, Livermore, Calif., April 29, 1994, pp. 61-64.

12. S. J. Yosim et al., Molten Salt Oxidation of HCB and Chlordane-Bench and Pilot Scale Tests, EPA-600/2-84-148, U.S. Environmental Protection Agency, Cincinatti, Ohio, September 1984.

13. Personal communication with Clyde Newman, January 1995.

14. C. R. Dempsey and E. T. Opplet, "Incineration of Hazardous Waste: A Critical Review Update," J. Air Waste Manage. Assoc. 43, $48-49$ (January 1993).

15. D. P. Hoffman et al., Guidelines for Benchmarking Thermal Treatment for Low-Level Mixed Waste, DOE/MWIP-19, Oak Ridge National Laboratory, Oak Ridge, Tenn., January 1994, p. 43. 
Appendix A

\section{SUBCONTRACT FOR ANALYSES}





\section{Appendix A. SUBCONTRACT FOR ANALYSES}

IT Air Quality Services had an existing subcontract to provide analytical services for other Martin Marietta Energy Systems, Inc., programs at Oak Ridge. The generic provisions of this subcontract were used as a basis for arranging for the MSO analyses. The planning and training part of this work included a plan document (IT project no. 406997, October 7, 1994).

The cost estimates for the analyses that we needed for our MSO experiments had three major components, as follows:

\begin{tabular}{|c|c|c|}
\hline Task & Description of task & Estimated cost $(\$)$ \\
\hline $1,2,5$ & $\begin{array}{l}\text { Planning, training, presample preparation, and } \\
\text { reporting }\end{array}$ & 30,000 to 32,000 \\
\hline 3,4 & Sample collection and analyses & 5,300 per MSO test \\
\hline 6 & $\begin{array}{l}\text { Quality assurance and quality control to validate } \\
\text { the above measurements to meet all regulatory } \\
\text { requirements }\end{array}$ & $\begin{array}{l}\text { Very high-perhaps about } \\
\text { three times the total for tasks } 1 \\
\text { and } 5\end{array}$ \\
\hline
\end{tabular}

We decided that task 6 was not necessary prior to our use of the analytical data. This resulted in estimated costs of about $\$ 138,000$ for 20 tests, or $\$ 63,000$ for 6 tests.

The actual final cost of the subcontract was $\$ 56,000$ for six tests. A final report (IT project no. 406997, January 1995) was received on February 7, 1995. The body of this report is included in Appendix C. 
Appendix B

CALCULATED EQUILIBRIUM RESULTS AT MSO CONDITIONS USING A COMPUTER PROGRAM FOR THERMODYNAMICS 
. 


\section{Appendix B. CALCULATED EQUILIBRIUM RESULTS AT MSO CONDITIONS USING A COMPUTER PROGRAM FOR THERMODYNAMICS}

Thermodynamic data can be used to calculate the equilibrium compositions as a limiting result for the molten salt oxidation (MSO) chemical reactions. Several important limitations should be noted, as follows:

1. If a stable substance or phase is not included, the results will be in error without any inherent indication of such errors.

2. Inconsistent thermochemical data from different selections of standard or reference states or errors of measurement will severely limit the accuracy of the results.

3. The nonideality of solutions may be an important factor and is usually not known.

4. The calculation of the equilibrium compositions gives a limiting condition but does not provide information on the kinetics rates of chemical reactions.

A series of multiphase equilibrium compositions was calculated for MSO conditions using the program "HSC Chemistry for Windows 1.2."* This program contains an enthalpy (H), entropy (S), and heat capacity data base for more than 7600 chemical compounds. It can be used to consider all possible chemical compounds in this data base for a specified set of chemical elements. Limitations 1 and 2 above are thus minimized as much as is practical. The computer program allows the use of activity coefficients, but the calculations were made for a gas phase and a single condensed phase with activity coefficients as for ideal solutions.

The calculations were made as follows:

1. All chemical elements in any of the compounds were listed.

2. The chemical elements for a search were specified.

3. All species (from the $>7600$ species in the data base) containing only the listed elements were used to produce an input file.

4. Unneeded species (known to be unimportant) were deleted to reduce the list to $\leq 150$ species. (Step 3 gave as many as 400 species for 10 elements.)

*Outokumpu Research Oy, P.O. Box 60, FIN-28101, PORI, Finland; telephone: 358-39-626-6111. 
5. The input amounts were specified. These were usually done as follows:

a. A total of 10,000 g-atoms of sodium was divided to give the final intended melt composition of $\mathrm{NaCl}, \mathrm{Na}_{2} \mathrm{CO}_{3}$, and other major amounts of sodium compounds.

b. A gas phase of $8000 \mathrm{~g}$-mol of $\mathrm{N}_{2}$ and $2000 \mathrm{~g}$-mol of $\mathrm{O}_{2}$ plus the oxygen products was assumed; the most common division was $800 \mathrm{~g}-\mathrm{mol} \mathrm{O}_{2}, 800 \mathrm{~g}-\mathrm{mol} \mathrm{CO}_{2}$, and $800 \mathrm{~g}$ $\mathrm{mol} \mathrm{H}_{2} \mathrm{O}$.

c. A total of $100 \mathrm{~g}$-atoms of each other element of interest was included in the form of plausible compounds with $\mathrm{O}_{2}, \mathrm{Cl}_{2}, \mathrm{Na}$, or $\mathrm{H}$ (e.g., $\mathrm{CaO}, \mathrm{BaCO}_{3}, \mathrm{H}_{3} \mathrm{PO}_{4}, \mathrm{BeO}, \mathrm{UO}_{3}$, $\mathrm{HgO}, \mathrm{CsCl}, \mathrm{Na}_{2} \mathrm{SO}_{4}, \mathrm{CeO}_{2}, \mathrm{ThO}_{2}, \mathrm{Al}_{2} \mathrm{O}_{3}, \mathrm{SiO}_{2}$, and $\mathrm{CoO}$ ).

6. All of the nongaseous species were combined into one condensed phase.

7. The temperature, pressure, $\Delta \mathrm{T}, \Delta \mathrm{P}$, and number of steps were specified.

8. The computer made an equilibrium calculation to produce an output file showing all species left after step 4.

9. The results were shown in the form of graphs or tables.

\section{B.1 PRIMARY MELT SALTS}

The MSO melt will react to near-equilibrium compositions with the waste feed and air. The primary salt feed is $\mathrm{Na}_{2} \mathrm{CO}_{3}$. The predominant waste compositions (by chemical elements) are large amounts of $\mathrm{C}$ and $\mathrm{H}$, major amounts of $\mathrm{O}_{2}$ and $\mathrm{Cl}_{2}$, and smaller amounts of many other elements. The other input stream is air with an excess of $\mathrm{O}_{2}$ over that required for reactions with the waste feed. All the acidic gases and compounds will react with the $\mathrm{Na}_{2} \mathrm{CO}_{3}$ to form sodium salts and release $\mathrm{CO}_{2}$. The $\mathrm{Na}_{2} \mathrm{CO}_{3}$ will also react with water vapor to form small amounts of $\mathrm{NaOH}$ and $\mathrm{CO}_{2}$. All organic compounds are oxidized or decomposed to trace concentrations. There is also an equilibrium between $\mathrm{Na}_{2} \mathrm{CO}_{3}$ and $\mathrm{NO}_{x}$ to form small amounts of $\mathrm{NaNO}_{2}$ and $\mathrm{NaNO}_{3}$. The $\mathrm{NaCl}$ and $\mathrm{NaOH}$ have significant vapor pressures at MSO temperatures.

Some examples of the equilibrium concentration results at $950^{\circ} \mathrm{C}$ for the sodium salts are given in Table B-1. The water vapor converts $\mathrm{Na}_{2} \mathrm{CO}_{3}$ to $\mathrm{NaOH}$ : about $1 \% \mathrm{NaOH}$ at $8 \% \mathrm{H}_{2} \mathrm{O}$ in the gas and $2 \% \mathrm{NaOH}$ at $20 \% \mathrm{H}_{2} \mathrm{O}$ in the gas (percent of sodium in the melt). The vapor pressure of $\mathrm{NaCl}$ increases with the fraction of sodium present as $\mathrm{NaCl}$. At $950{ }^{\circ} \mathrm{C}$, the values are as follows: $2 \%$ in the melt gives $0.02 \mathrm{vol} \% \mathrm{NaCl}$ in the gas, $20 \%$ in the melt gives $0.2 \mathrm{vol} \%$ in the gas, and $60 \%$ in the melt gives $0.6 \mathrm{vol} \%$ in the gas. 
Table B-1. Some typical equilibrium amounts vs melt and gas compositions ${ }^{a}$

\begin{tabular}{|c|c|c|c|c|c|c|}
\hline & \multicolumn{6}{|c|}{ Calculation } \\
\hline & 1 & 2 & 3 & 4 & 5 & 6 \\
\hline \multicolumn{7}{|c|}{ Input amounts, g-mol } \\
\hline $\mathrm{Na}_{2} \mathrm{CO}_{3}$ & 4000 & 4900 & 2000 & 4000 & 4000 & 4000 \\
\hline $\mathrm{NaCl}$ & 2000 & 200 & 6000 & 2000 & 2000 & 2000 \\
\hline $\mathrm{N}_{2}$ & 8000 & 8000 & 8000 & 8000 & 8000 & 8000 \\
\hline $\mathrm{O}_{2}$ & 800 & 800 & 800 & 2000 & 800 & 800 \\
\hline $\mathrm{CO}_{2}$ & 800 & 800 & 800 & 3 & 800 & 1200 \\
\hline $\mathrm{H}_{2} \mathrm{O}$ & 800 & 800 & 800 & 10 & 2400 & 10 \\
\hline \multicolumn{7}{|c|}{ Other amounts at $950^{\circ} \mathrm{C}, \mathrm{g}-\mathrm{mol}$} \\
\hline $\mathrm{NaOH}$ & 135 & 140 & 115 & 19 & 200 & 10 \\
\hline $\mathrm{NaCl}(\mathrm{g})$ & 15 & 2 & 35 & 15 & 20 & 15 \\
\hline $\mathrm{Na}_{2} \mathrm{Cl}_{2}(\mathrm{~g})$ & 2.0 & $<0.1$ & 13 & 1.9 & 2 & 2 \\
\hline $\mathrm{NaOH}(\mathrm{g})$ & 0.7 & 1 & & $<0.1$ & 2 & 0.1 \\
\hline $\mathrm{NO}(\mathrm{g})$ & 1.6 & 1.6 & 1.6 & 2.5 & 2 & 1.6 \\
\hline $\mathrm{NaNO}_{2}$ & 0.2 & 0.2 & 0.2 & 3.5 & 0.2 & 0.2 \\
\hline $\mathrm{Na}_{2} \mathrm{O}$ & 0.8 & 0.8 & $<0.1$ & 0.8 & 0.1 & $<0.1$ \\
\hline
\end{tabular}

${ }^{a}$ Basis: about 10,000 g-atoms of sodium salts in melt and $8000 \mathrm{~g}$-mol of $\mathrm{N}_{2}$ from air feed. Results from "HCS Chemistry for Windows 2.0."

The equilibrium NO concentrations at $950^{\circ} \mathrm{C}$ are $250 \mathrm{ppm}$ for air and $160 \mathrm{ppm}$ for $80 \% \mathrm{~N}_{2} / 8 \%$ $\mathrm{O}_{2}$. The equilibrium concentrations of the other nitrogen oxides are much lower. The equilibrium $\mathrm{NaNO}_{2}$ concentrations in the melt are $0.002 \mathrm{~mol} \%$ with $8 \% \mathrm{CO}_{2}$ and $0.035 \mathrm{~mol} \%$ for air. This difference causes a short-term spike of high $\mathrm{NO}_{x}$ concentration when carbon-containing wastes are fed to a $\mathrm{Na}_{2} \mathrm{CO}_{3}$ melt that is in equilibrium with air.

\section{B.2 EQUILIBRIUM COMPOSITION FOR SMALL AMOUNTS OF OTHER METALS}

The equilibrium composition and the volatility of metals are indicators of the retention of metals by the melts. Some results from the thermochemical equilibrium calculations are summarized in Table B-2. 
Table B-2. Equilibrium compositions and volatilities for small amounts of metals ${ }^{a}$

\begin{tabular}{|c|c|c|c|}
\hline \multirow[b]{2}{*}{ Metal(s) } & \multirow{2}{*}{$\begin{array}{l}\text { Predominant } \\
\text { product }\end{array}$} & \multicolumn{2}{|c|}{ Volatile products } \\
\hline & & Metal or compound & $\begin{array}{c}\text { Amount } \\
\left(\mathrm{g}-\mathrm{mol} \text { at } 950^{\circ} \mathrm{C}\right)\end{array}$ \\
\hline Cs & $\mathrm{CsCl}$ & $\mathrm{CsCl}$ & 16 \\
\hline $\mathrm{Ce}$ & $\mathrm{CeO}_{2}$ & & \\
\hline $\mathrm{Ba}$ & $\mathrm{BaCO}_{3}$ & $\mathrm{BaO}$ & 0.8 \\
\hline $\mathrm{Al}+\mathrm{Si}$ & $\mathrm{NaAlSiO}_{6}(\mathrm{D})$ & & \\
\hline $\mathrm{Al}$ & $\mathrm{NaAlO}_{2}$ & & \\
\hline $\mathrm{Si}$ & & & \\
\hline Co & $\mathrm{CoO}$ & & \\
\hline $\mathrm{Ca}$ & $\mathrm{CaO}$ & & \\
\hline $\mathrm{U}+\mathrm{Ba}$ & $\mathrm{BaO} \cdot \mathrm{UO}_{3}$ & & \\
\hline $\mathrm{U}$ & $\mathrm{Na}_{2} \mathrm{O} \cdot \mathrm{UO}_{3}$ & & \\
\hline$S$ & $\mathrm{Na}_{2} \mathrm{SO}_{4}$ & & \\
\hline $\mathrm{P}$ & $\mathrm{NaPO}_{4}$ & $\mathrm{P}_{2} \mathrm{O}_{4}$ & $\sim 0$ \\
\hline $\mathrm{Hg}$ & $\mathrm{Hg}(\mathrm{g})$ & $\mathrm{Hg}$ & 99 \\
\hline $\mathrm{Fe}$ & $\mathrm{NaFeO}_{2}$ & & \\
\hline Th & $\mathrm{ThO}_{2}$ & & \\
\hline $\mathrm{Be}$ & $\mathrm{BeO}$ & $\mathrm{Be}(\mathrm{OH})_{2}$ & $\sim 0$ \\
\hline $\mathrm{Ag}$ & $\mathrm{Ag}$ & $\mathrm{AgCl}$ & $\sim 0$ \\
\hline $\mathrm{Cd}$ & $\mathrm{CdO}$ & $\mathrm{Cd}$ & 0.03 \\
\hline $\mathrm{Cr}$ & $\mathrm{Na}_{2} \mathrm{CrO}_{4}$ & & \\
\hline As & $\mathrm{Na}_{3} \mathrm{AsO}_{4}$ & & \\
\hline $\mathrm{Pb}$ & $\mathrm{PbO}$ & $\mathrm{PbO}$ & 0.03 \\
\hline $\mathrm{Se}$ & $\mathrm{SeO}_{2}(\mathrm{~g})$ & $\mathrm{SeO}_{2}$ & 99 \\
\hline
\end{tabular}

${ }^{a}$ Conditions (with exceptions as noted):

Input gas: $8000 \mathrm{~g}$-mol $\mathrm{N}_{2}, 800 \mathrm{~g}$-mol $\mathrm{O}_{2}, 800 \mathrm{~g}$-mol CO $\mathrm{CO}_{2}, 800 \mathrm{~g}$-mol $\mathrm{H}_{2} \mathrm{O}$

Input melt: $400 \mathrm{~g}-\mathrm{mol} \mathrm{Na}_{2} \mathrm{CO}_{3}, 2000 \mathrm{~g}$-mol NaCl

Calculation: $\mathrm{T}=700$ to $1100^{\circ} \mathrm{C}, \Delta \mathrm{T}=20^{\circ} \mathrm{C}$

Other metal inputs: $100 \mathrm{~g}$-atm 
Appendix C

"SAMPLING REPORT FOR WASTE STREAM COMBUSTION PRODUCTS

FROM A MOLTEN SALT OXIDATION SYSTEM

AT OAK RIDGE NATIONAL LABORATORY"

(ATTACHMENTS NOT INCLUDED)

IT Project No. 406977 



\title{
Sampling Report for Waste Stream Combustion Products from \\ A Molten Salt Oxidation System at Oak Ridge National Laboratory Oak Ridge, Tennessee
}

\author{
Prepared for: \\ Martin Marietta Energy Systems, Inc. \\ P.0. Box 2002 \\ Oak Ridge, Tn 37831
}

\author{
by: \\ IT Air Quality Services \\ 312 Directors Drive \\ Knoxville, TN 37923 \\ IT Project Number 406977 \\ Test Dates \\ October 24-27 and 31, November 1 and 2, 1994 \\ Report Date \\ January 1995
}




\section{Table of Contents}

List of Tables/List of Figures $\ldots \ldots \ldots \ldots \ldots \ldots \ldots \ldots \ldots \ldots \ldots \ldots \ldots \ldots \ldots \ldots$

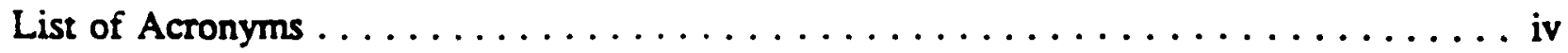

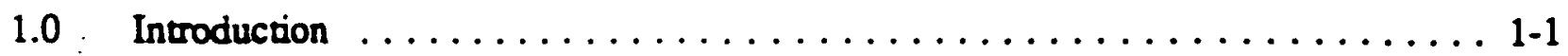

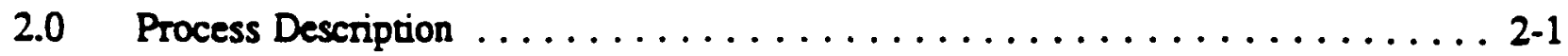

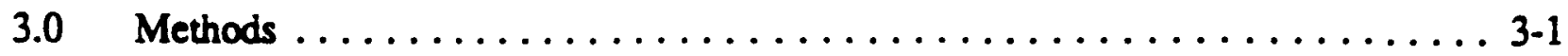

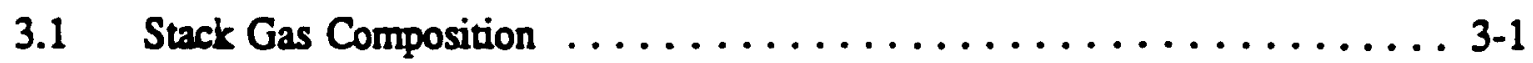

3.1.1 Carbon Dioxide and Oxygen $\ldots \ldots \ldots \ldots \ldots \ldots \ldots \ldots \ldots$ 3-1

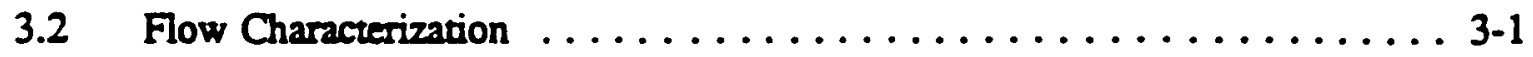

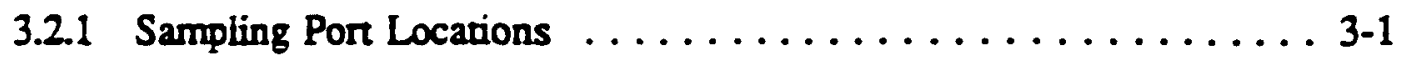

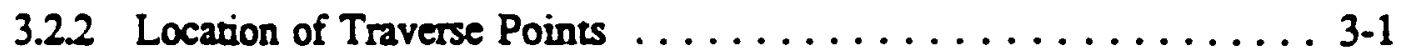

3.2.3 Velocity and Volumetric Flow Measurements .......... 3-2

3.2.4 Temperature Measurements . . . . . . . . . . . . . 3-2

3.2.5 Moisure Determinations . . . . . . . . . . . . . . . . .

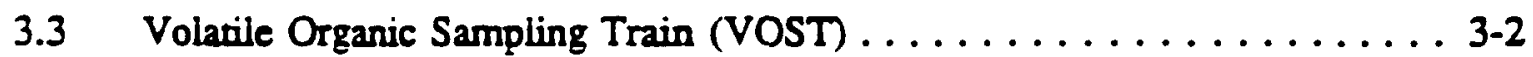

3.4 Dioxins \& Furans/Semi-Volatile Train (M23/MMS) . . . . . . . . . . 3-3

4.0 Equipment Calibrations . . . . . . . . . . . . . . . . . . 4-1

4.1 Equipment Calibracion Overview ...................

4.2 Calibration Procedures . . . . . . . . . . . . . . . . . . 4-1

4.2.1 Dry Gas Meters/Orifice Meters . . . . . . . . . . . . 4-1

4.2.2 Thermocoupies and Thermocouple Readouts ......... 4-2

$5.0 \quad$ Results .............................. $5-1$

5.1 Flow Rate and Gas Composition Results $\ldots \ldots \ldots \ldots \ldots \ldots \ldots$ 5-1

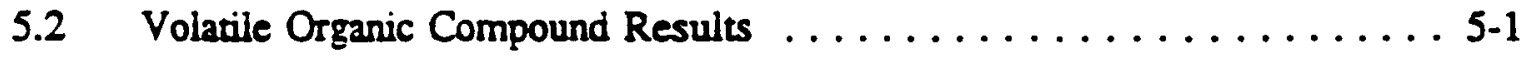

5.3 Modified Method 5 Results . . . . . . . . . . . . . . . 5-2

5.3.1 Resuits from Isokinetic Sampling $\ldots \ldots \ldots \ldots \ldots \ldots \ldots$ 5-2

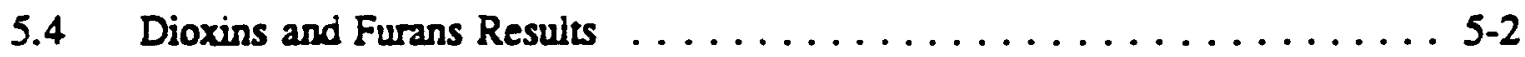

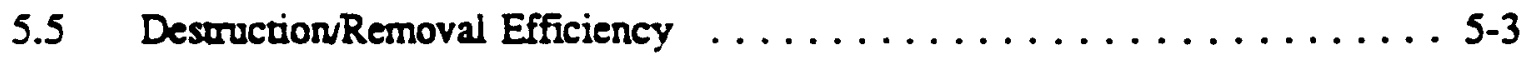

5.6 Total Toxiciry Equivalent Concentrations $\ldots \ldots \ldots \ldots \ldots \ldots \ldots \ldots$ 5-3

5.7 Test 4 background Sample Concentrations $\ldots \ldots \ldots \ldots \ldots \ldots \ldots$ 5-3 


\title{
Table of Contents (Continued)
}

\author{
Attachment A - Field Data (VOST) \\ Attachment B - Calculations (VOST) \\ Attachment C - Field Data (M23/MM5) \\ Attachment D - Calculations (M23/MM5) \\ Attachment E - Calculations Isokinetic, Volume @ STP, \& Gas Flow Rate (DSCFM) \\ Attachment F - Test Parameters \\ Attachment G - Calibrations \\ Attachment H - Analysis Request/Chain of Custody Record and Sample Collection Sheets \\ Attachment I - Analytical Laboratory Results
}




\section{List of Tables}

Table

3-1 Method for Determination of Stack

Gas Moisure Content .......................... 3-2

3-2 Determination of Volatile POHCs \& PIC

from a Waste Stram ............................ 3-3

3-3 Method for Determination of Flue Gas

Semi-Volatile, Dioxin/Furans $\ldots \ldots \ldots \ldots \ldots \ldots \ldots \ldots \ldots \ldots \ldots$.

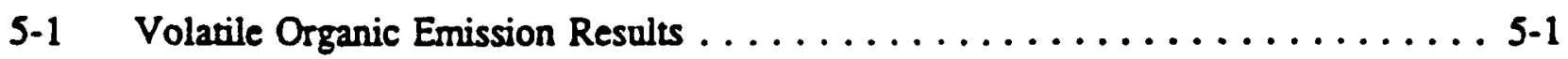

5-2 Semi-volatile Organic Emission Results . . . . . . . . . . . . . . 5-2

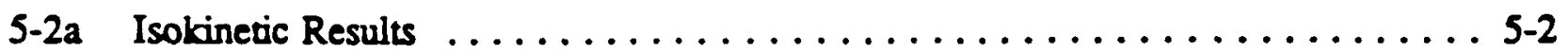

5-3 Dioxins \& Furans Emission Results . . . . . . . . . . . . . . . 5-2

$5-4$ Destruction Removal Efficiency . . . . . . . . . . . . . . . . 5-3

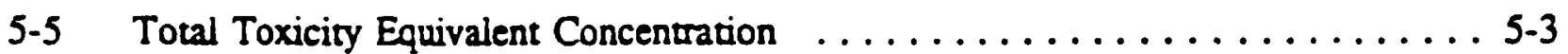

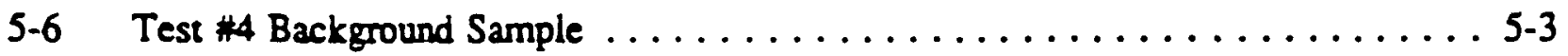

\section{List of Figures}

Figure

3-1 Schematic of Vost Sampling Train $\ldots \ldots \ldots \ldots \ldots \ldots \ldots \ldots \ldots \ldots \ldots . \ldots \ldots$

3-2 Schematic of Method 23 \& Modified Method 5 Train ............ 3-4

3-3 Schematic of Method 23 \& Modified

Method 5 Sample Recovery ...................... 3-4 


\section{List of Acronyms}

$\begin{array}{ll}\text { AQS } & \text { Air Quality Services } \\ \text { CFR } & \text { Code of Federal Regulations } \\ \text { CLP } & \text { Contract Laboratory Program } \\ \text { Chem Tech } & \text { Chemical Technology Division (ORNL) } \\ \text { CO }_{2} & \text { Carbon Dioxide } \\ \text { COC } & \text { Chain of Custody } \\ \text { EPA } & \text { Environmental Protection Agency } \\ \text { HEPA } & \text { High Efficiency Particulate Filter } \\ \text { MSO } & \text { Molten Salt Oxidation } \\ \text { M23 } & \text { USEPA Reference Method 23 } \\ \text { MM5 } & \text { Modified Method 5 } \\ N_{2} & \text { Nitrogen } \\ \text { Na.CO, } & \text { Sodium Carbonate } \\ \text { ORNL } & \text { Oak Ridge Nationail laboratory } \\ \text { PCDD } & \text { Polychlorinated Dibenzo-p-dioxins } \\ \text { PCDF } & \text { Polychlorinated Dibenzofurans } \\ \text { PIC } & \text { Products of Incomplete Combustion } \\ \text { POHC } & \text { Principal Organic Hydrocarbon } \\ \text { QA } & \text { Quality Assurance } \\ \text { QC } & \text { Quality Control } \\ \text { RCRA } & \text { Resource Conservation \& Recovery Act } \\ \text { RFA } & \text { Request for Analysis } \\ \text { TCL } & \text { Target Compound List } \\ \text { TSCA } & \text { Toxic Substances Control Act } \\ \text { USEPA } & \text { U. S. Environmental Protection Agency } \\ \text { VOST } & \text { Volatile Organic Sampling Train } \\ & \end{array}$




\subsection{Introduction}

IT Air Quality Services personnel conducted emission testing on a Molten Salt Oxidation (MSO) unit for Martin Marietta Energy Systems, Inc., Chemical Technology Division at the Oak Ridge National Laboratory (ORNL) located in Oak Ridge, Tennessee. Six MSO emission tests were performed from October 24 through November 2, 1994, with an additional test run performed on October 31, 1994 of the ambient air in the MSO lab to provide a background sample. The information obtained during the test will be used to supply research information concerning the unit and how it operates under different process conditions. The main objective of the tests was to analyze waste stream combustion products from the MSO unit while it was processing hazardous material. During the tests, sampling was conducted for volatile and semi-volatile organic products of incomplete combustion (PICs), polychlorinated dibenzo-p-dioxins (PCDDs) and polychlorinated dibenzofurans (PCDFs).

Three EPA test methods (Method 23. Modified Method 5, and VOST) were used to collect samples at each test condition. The MSO unit was tested under six different conditions. The forth test was a background sample of the lab. Method 23 and Modified Method 5 were performed. the MSO unit was not operating. The results of all seven tests are presented in this report.

IT-AQS personnel involved in the stack testing were:

Randiall Moore

Michael De Socio

Mike Mowery

Kim Cole

During the test procedures the MSO process was controlled by Jeff Rudolph and Paul Haas, from the Chemical Technology Division ar ORNL.

The EPA Method 23 and Modified Method 5 (M23/MM5) isokinetic sampling train was assembled and operated by Michael De Socio. The VOST sampling train was assembled and operated by Mike Mowery.

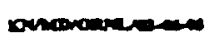




\subsection{Process Description}

The MSO process involves the oxidation and vaporization of liquid hydrocarbon waste at high temperature in the presence of molten $\mathrm{Na}_{2} \mathrm{CO}_{3}$. The hazardous organic liquids are destroyed. producing $\mathrm{CO}_{2}$ and $\mathrm{H}_{2} \mathrm{O}$ vapors while retaining inorganic components such as heavy metals and acid gases in the salt.

The experimental equipment consists of an alumina crucible ( 6 in. diam. and $3 \mathrm{ft}$ long) inserted in an Inconel vessel which is surrounded by a furnace. Incoming air (1/4 in.) and feed lines (1/8 in.) are set in an annular configuration inside an alumina tube ( 2 in. diam) which is inserted in the top of the vessel and ends $1 / 2$ in. from the crucible bottom. The off-gas line passes through a knockout drum, prefilter, and High Efficiency Particulate Air (HEPA) filter before entering a duct which carries the exhaust to the Building 3039 stack. There is also a storage vessel for the feed. The entire system (excluding the exhaust ductwork) is contained in an $8 \times 8 \times 8 \mathrm{ft}$. ventilated enclosure.

The process begins with the introduction of salt to the alumina crucible and by slowly raising its temperature to $1650^{\circ} \mathrm{F}\left(900^{\circ} \mathrm{C}\right)$. The air and dispersing gas flows are then started and slowly raised to standard operating conditions. Once this is achieved, the feed (waste) pump is started and the flow is brought to the desired level. The feed and a dispersing gas (either air or $\mathrm{N}_{2}$ ) mix together in the inner tube of the injector. Air travels down the annulus tube. The injector then sprays the liquid and gases into the molten sait through the alumina tube. Here the organics are oxidized while the heavy metals are retained in the salt marrix. The gases and any particulate caught within. pass through a knockout drum (a solids collection chamber) and pass through a prefilter and a HEPA filter. Here a sample of gases are eaken for analysis. The off-gases are then routed out of the enclosure through a duct to the building 3039 stack for final discharge into the atmosphere. 


\subsection{Methods}

USEPA mechods were used whenever possible. However, the small size of the MSO unit restricted access to the exhaust duct, requiring cerain modifications to the standard methods. The following methods descriptions include narrative on those modifications as applicable.

\subsection{Stack Gas Composition}

The concentrations of water, carbon dioxide $\left(\mathrm{CO}_{2}\right)$, oxygen $\left(\mathrm{O}_{2}\right)$, carbon monoxide $(\mathrm{CO})$, were recorded during each test run. The $\mathrm{CO}_{2}, \mathrm{O}_{2}$, and water concentrations were used to determine the average molecular weight of the gas stream which is required to calculate stack volumetric flow rates.

\subsubsection{Carbon Dioxide and Oxygen}

The carbon dioxide $\left(\mathrm{CO}_{3}\right)$, and oxygen $\left(\mathrm{O}_{2}\right)$, concentrations in the exhaust gas were calculated for each run based on complete combustion of the feed materials and conservation of mass. Once concentrations were determined in the gas stream, equations from CFR 40, Part 60, Appendix A. Mechod 3, were used to determine the dry molecular weight of the gas.

\subsection{Flow Characterization}

\subsubsection{Sampling Port Locations}

Due to the unique configuration of the MSO unit 40 CFR, Part 60 Appendix A Method 1 could only be used for guidance. The point of extraction for the M23/MMS isokinetic sampling was the threaded por on the exhaust line approximately 2 diameters up stream from the any disturbances and at least 8 diamerers down stream from any disturbances. The VOST port was located. approximately 15 diameters upstream of the exit plane of the exhaust pipe.

\subsubsection{Locatton of Traverse Points}

Due to the small size of the exhaust pipe (1.25 inches in diameter) the sample was extracted from one single point Knife edge nozzles were specifically design for sampling the MSO unit. The nozzle was piaced at the central stream line of the exhaust flow.

\subsubsection{Velocity and Volumetric Flow Measurements}

The velocity of the gas stream could not be determined through standard procedures as outlined in 40 CFR. Par 60 Appendix A Method 2. The small diameter in the exhaust pipe and low 
volumetric flow rate would not permit the use of a pitot tube. The use of a hot wire or a rotameter device would also prove to be inadequate due to the chemical make up of the gas stream and the elevated temperanure. The gas velocity, and volumetric flow rate was calculated by using known input parameters with the Ideal Gas Law and Conservation of Mass. The equations were built into a computational spread sheet so that velocity could be calculated during each run of the isokineric sampling train. After the velocity was determined, the volumetric flow rate and the change in the velocity pressure at the nozzle could be determined so that isokinetic sampling could be maintained. The velocity and velocity pressure were recorded every fifteen minutes during each run.

\subsubsection{Temperature Measurements}

The temperature of the stack gas was measured using K-type thermocouples and dedicated digital temperature readouts. The temperature was measured every fifteen minutes and was located down stream from the point of extraction (approximately 4 inches from the nozzle tip). The stack temperanures were arithmetically averaged and used to calculate the volumetric flow rates at standard and dry standard conditions. Detailed accuracy and calibration information for the $\mathrm{K}$-type thermocouples is discussed is section 4.2.2.

\subsubsection{Moisture Determinations}

The moisture content of the stack gas was determined using procedures outlined in 40 CFR 60: Appendix A. Reference Method 4. The Method 4 sampling was incorporared with the isokinetic sampling train. The moisture was determined for each sampling train by gravimetrically measuring the weight gain of the XAD trap and the chilled impingers after each sampling run. The specific procedures are outlined in Table 3-1.

\subsection{Volatile Organic Sample Train (VOST) Method 0030}

The VOST Method 0030 was used to collect samples for measurement of volatile principal organic hazarious constituents (POHCs) and products of incomplete combustion (PICs) from the exhaust stream. This procedure is located in. Test Methods for Evaluating Solid Waste, Physical/Chernical Methods, SW-846. 3rd Edition Method 0030, VOST. The VOST is designed to extract a sample from a gas stream through a heated probe into a condenser were the gas is - cooled and than pulled through a pair of sorbent resin cartridges where the volatile organics are collected. The tront carridge contains approximately $1.6 \mathrm{~g}$ of Tenax@ and the second cartridge 


\section{Table 3-1}

\section{Method for Determination of Stack Gas Moisture Content}

EPA Reference Method 4

Sample Name: $\quad$ M23/MMS sample train impinger solution

M23/MM5 sample train silica gel

M23/MMS sample train XAD-2 resin

Sample

Holding Time:

Equipment:

Procedures:

Reference:
None, perform upon collection

Combination EPA method 23/modified 5 sampling train's impinger weights and the XAD-2 trap. pre and post test procedure.

Increase in volume of impinger solution was measured by weighing to the nearest $0.1 \mathrm{~g}$.

Increase in weight of the silica gel was measured to the nearest $0.1 \mathrm{~g}$.

Increase in weight of the XAD-2 trap was measured to the nearest $0.1 \mathrm{~g}$

Flue gas Moisture content was calculated using equations provided in the method referenced below.

Code of Federal Requlations. 40 CFR 60. New Source Performance Standards. Test Methods and Procedure. Appendix A. Reference Method 4. 
contains approximately $1 \mathrm{~g}$ each of Tenax (B) and petroleum based charcoal. To determine the mass of volatile compounds collected, the cartridge was analyzed, using EPA Method 8240.

A special consideration used for the MSO tests was that "slow vost" operating procedures were used. The VOST sampling train was operated at a reduced flow rate of $0.5 \mathrm{~L} / \mathrm{min}$. for $40 \mathrm{~min}$. to collect a nominal volume of $20 \mathrm{~L}$ for each pair of sorbent traps. The reduced sampling rate enhances collection efficiency and retention of the more volatile species.

The sampling equipment and the procedures for collecting the volatile organic compounds are summarized in Tables 3-2. This table aiso provides information regarding sampling frequency and the reference methods that were followed. Figure 3-1 shows a schematic of the VOST train and its serial connections as it was employed for sampling the MSO waste stream.

\subsection{Method 23/Modifled Method 5 (M23/MM5) Sampling Procedure}

USEPA Reference Methods 23 from 40 CFR, Part 60 Appendix A, was used to collect and analyze sampies for dioxins and furans. SW-846 Method 0010 (MMS) was used to target semivolatile organic compounds.

The M23 and MM5 were combined into a single sampling train. The identical characteristics and configurations of the sampling trains and specific analyses permits both sample recoveries through a single train. The primary objective was to obtain samples using the recovery process in M23 and then splitting the sample in half to perform two different analyses.

The train was designed so that gaseous and particulate pollutants are withdrawn from an emission source at an isokinetic sampling rate and collected in a multi-component sampling train. Principal components of the train included a high-efficiency glass filter and a packed bed of porous polymeric absorbent resin. The filter was used to collect organic-laden pariculate materials and the porous poiymeric resin to absorb semi-volatile organic species. The samples were analyzed for PCDDs and PCDFs using EPA Method 8290 (modified). To analyze the samples for semi-volatile organic compounds. EPA Method 8270 was used. 
Table 3-2

Determination of Volatile POHCs \& PIC from a Waste Stream EPA Reference Method 0030 (VOST)

Sample Name: VOST sample cartridge (Tenax trap)

Sampler: $\quad$ VOST sampling operator

Process

Location: $\quad$ MSO exhaust duct

Equipmenr EPA Method 0030 sampling train, sorbent cartridges, glass culture tubes with screw top caps, aluminum foil, and glass vials $(40 \mathrm{ml})$ with screw top caps with teflon-lined septe.

Collecrion

Frequency: Continuousiy, with replacement of sorbent tube pairs every $\mathbf{4 0}$ minutes; four pair constituted one run.

Procedures: $\quad$ Sorbent Tube Preparation and Handling The procedures for prepanng, handling. stonng, and analyzing the rubes were performed as described in the EPA protocol referenced below. Sorbent maternal (Tenax resin and charcoal) was Soxhlet extracted. vacuum dried. thermally conditioned with organc-free nitrogen, and loaded into ubes which are then subsequently pressure leak tested. Two paur of VOST tubes were spiked with surrogate compounds and analyzed by the analytical laboratory as blanks.

The sorbent tubes were protected from contamination by placing them in culture tubes durng shipping and storage. These tubes are then placed in clean glass or metal containers which contain clean charcoal. The tubes were stored at $<4^{\circ} \mathrm{C}$ in a freezer in an area free from sources of contamunation prior to shipment. For shipment to the site. the tubes were pacied separately and kept on ice in insulated containers.

At the sampling site. VOST tubes were stored on ice until needed. VOST samples were then re-packed on ice and shipped. along with sample documentanon.

\section{VOST Operarion}

The sampie collection procedures described in the EPA protocol reierenced below were sinctly followed. As described in the protocol. the dry gas meter was calibrated before arriving to the test site. and the sampling trin was cleaned and assembled before installing the resin oubes. The ends caps to the rubes were stored in a clean glass jar while the nubes were in the tran. The train was 
leak tested near $10 \mathrm{in.} \mathrm{Hg}$ in such a manner as to prevent exposure of the train to the ambient air.

Before sampling, ice water was circulated through the condenser. and the probe was purged of ambient air and inserted into exhaust flue. The probe was heated to $130^{\circ}$ to $150^{\circ} \mathrm{C}\left(266^{\circ}\right.$ to $\left.302^{\circ} \mathrm{F}\right)$. The train was operated under "slow VOST" conditions, i.e., at the reduced sample flow rate discussed in the protocol. The flue gas was sampled at a rate of $0.5 \mathrm{~L} / \mathrm{min}$ for $40 \mathrm{~min}$. to collect a nominal volume of $20 \mathrm{~L}$ for each pair of sorbent wubes. Four pairs of tubes were collected during each of the test runs. After collecting the samples, the tube pairs were removed from the VOST, their end caps replaced. retumed to their culture tubes, and stored in coolers on ice.

During every other nu. the end caps were removed from a field blank tube pair to simulate the handling of the test sample tubes. The tubes remained open for approximately 10 minutes. One set of trip blanks were included and remain on site until all data was collected. The laboratory will include any laboratory blanks that are necessary.

Samples were placed on ice in clean coolers, which was stored in an area from other samples and contamination sources. The VOST condensate samples were shipped in a separate cooler and preserved by chilling to $<4^{\circ} \mathrm{C}$.

References: $\quad$ Test Methods for Evaluating Solid Waste, Physical/Chemical Methods. SW-846, 3rd Edition Method 0030, VOST

Protocol for the collection and Analysis of Volatile POHCs Using the VOST, EPA-600/8-84-007. 


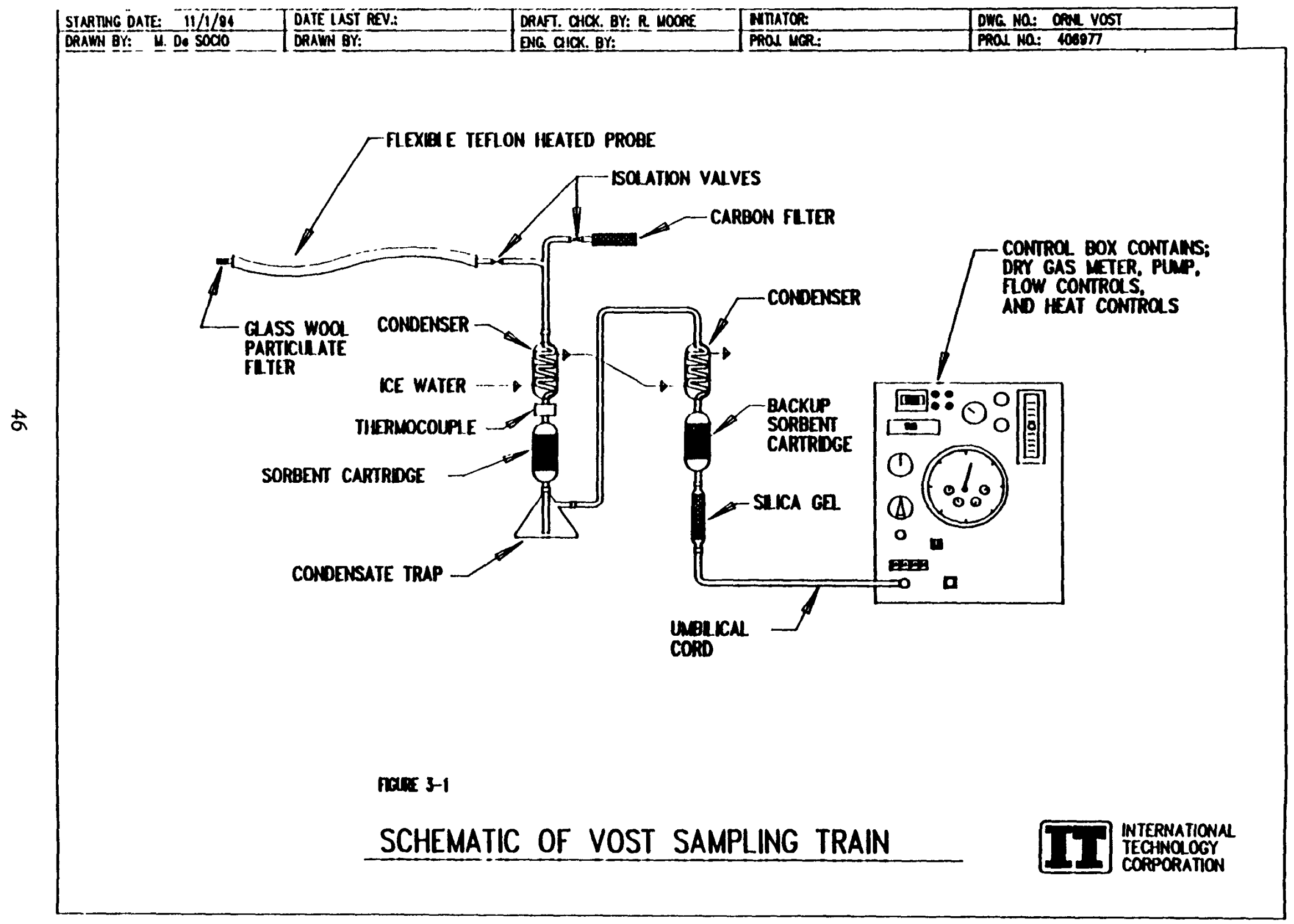


The sampling equipment and the procedure for collecting the samples are summarized in Tables 3-3. This table also provides information regarding sampling frequency and the reference methods that were followed. Figure 3-2 shows a schematic of M23/MMS train as it was employed for sampling the MSO waste stream. Figure 3-3 describes the steps that were followed to recover the samples following each sampling run. 
Table $3 \cdot 3$

Method for Determination of Dioxin/Furans \& Semi-Volatile

EPA Reference Method 23 and Modified Methods 5

Sample: $\quad$ MMS Semi-volatile

M23 dioxins, furans

Sampler: $\quad$ Sampling team

Process

Location: $\quad$ MSO exhaust flue

Equipment: Combination EPA Method 23/EPA Modified Method 5 sampling train. pear dish with tared glass fiber filter. sorbent trap (XAD-2), sample storage containers with Teflono -lined caps, aluminum. and chemical reagents.

Collection

Frequency: Continuously, for approximately four hours with at least three dry standard cubic meters of sample collected.

Procedure: $\quad$ Sorbent Trap Preparation

The procecure for prepanng, handling, storing, and analyzing the traps are described in the EPA method referenced below. As described in the method. the XAD-2 sorbent material was cleaned by Soxhlet extraction and oven dried. A portion of the prepared resin was spiked with a surrogate mixture and analyzed as a laboratory blank to confirm that the resin is free of significant background contamination.

All glassware componenus of the sampling train upstream of the absorbent material were cleaned as described in Section 3A of the "Manual of Analytical Methods for Analysis of Human and Environmental Sampies". Special care was taken to remove residual silicone grease sealani on ground glass connections. Each sorbent trap was filled with approximately 50 grams of clean XAD-2 resin. During the resin preparation. a 200 microgram spike of isotopically labeled polychlorinated dibenzo-p-dioxins (PCDDs) and polychlonnated diberzotiurans (PCDFs) was spiked onto each XAD2 resin trap. This isotopically labeled PCDD/PCDF spike serves as a sampling surrogate compound to indicate losses due to the sampling process.

For transpor to the field. the resin traps had their ends sealed with Teflono tape, wrapped in aluminum foil, sealed in Zip-lock bags and packed in a clean sample cooler. In the field. the traps were removed only when ready for numbering and installation in the sampling train. At the end of each test. the sample trap and other 
train components were removed and the samples were documented. The samples were stored at approximately $4^{\circ} \mathrm{C}$ in insulated coolers in a storage area away from sources of fugitive contamination.

\section{M23/MMS Train Operation}

EPA method 1 was followed to the extent possible. However, due to the unique configuration of the MSO Method 1 criteria were used as guidelines only. The point of sample extraction was the threaded port on the exhaust line approximately 2 diameters up stream from any disturbance and 8 diameters down stream from any disturbance. The volumetric flow rate were determined by calculation based on measured input parameters. using the Ideal Gas Laws and conservation of mass. The total sampling time during a run will be about four hours with at least three dry standard cubic meters of sample collected.

The sampling train was assembled with a tared glass fiber filter, and $100 \mathrm{ml}$ of deionized water in the first and second impinger. The thind impinger was empty initially. The forth impinger contained silica gel weighed to the nearest $0.1 \mathrm{~g}$. EPA Method 5 procedures were followed for pretest and post test leak check. isokinetic sampling rate. and data recording. An activated charcoal filter was placed on the end of the probe to ensure no ambient contaminants were allowed to enter the train during leak checks. Fig" 2-3 shows the schematic of the sampling train.

\section{M23/MMS Sample Recovery}

At the end of sampling, the nozzie was sealed in the MSO by closing a leak free valve, then the heated sampling line was removed from the exhaust flue. When the probe cooled sufficiently to be handled safely, the particulate matrer on the tip of the probe was wiped off. The probe was removed from the sampling train. both ends sealed off with alumimum foil, and moved intact to a clean enciosed area for sample recovery. The sample was recovered from the train as follows:

The paricuiate filter was removed from its holder and carefully placed inso its original, numbered perri dish. which was sealed with tape and placed in a piastic bag.

The sorbent trap was removed from the train. tightly capped, wrapped in aluminum foil. sealed in a plastic bag, and stored for shipment.

The intemal surface of the nozzle. probe and front half of the filter holder ano all connecting glassware was rinsed with acetone three times. The aceione rinse was followed by rinsing three times with 
Table $3-3$ continued

methylene chloride. These rinses were combined and placed in a labeled sample jar with a Teflono-lined lid. The rinse was repeated. with toluene as the rinse solvent, and placed into a separate sample jar.

The back half of the filter holder. condenser, comnecting glassware between the filter holder and condenser, and the XAD-2 trap comecting glassware was rinsed three times with acetone. The acetone rinse was followed by three 5-minute soaking/rinses with three separate portions of methylene chloride. These rinses were added to the contents of the probe rinse samples and the liquid level marked on the collection container. The methylene chloride rinsing procedure was repeated using toluene as a rinsing solvent. The tolvene rinses were added to the contents, of the probe toluene rinse and the liquid level marked on the collection container.

Impinger solution, silica gel, and XAD-2 trap were reweighed to the nearest $0.1 \mathrm{~g}$ to determine the amount of moisture collection. The impinger water was discarded after the measuring and recording of its weight.

A sample of all rinsing agents was taken for a reagent blank

A schematic of the train sample recovery scheme is presented in Figure 3-3. All of the samples components were assigned unique tracking numbers and labeled with data and test-nun number. The sampies will be recorded in the field $\log$ book and packed in a sample holding area away from sources of fugitive contamination.

References: $\quad$ Code of Federal Requlation, 40 CFR 60. New Source Performance Standards. Test Methods and Procedure. Appendix A, Reference Methods 4, 5, 23.

Test Mechods for Evaluating Solid Waste, Physical Chemical Methods. SW-846. 3rd Edition. Reference Method 0010 


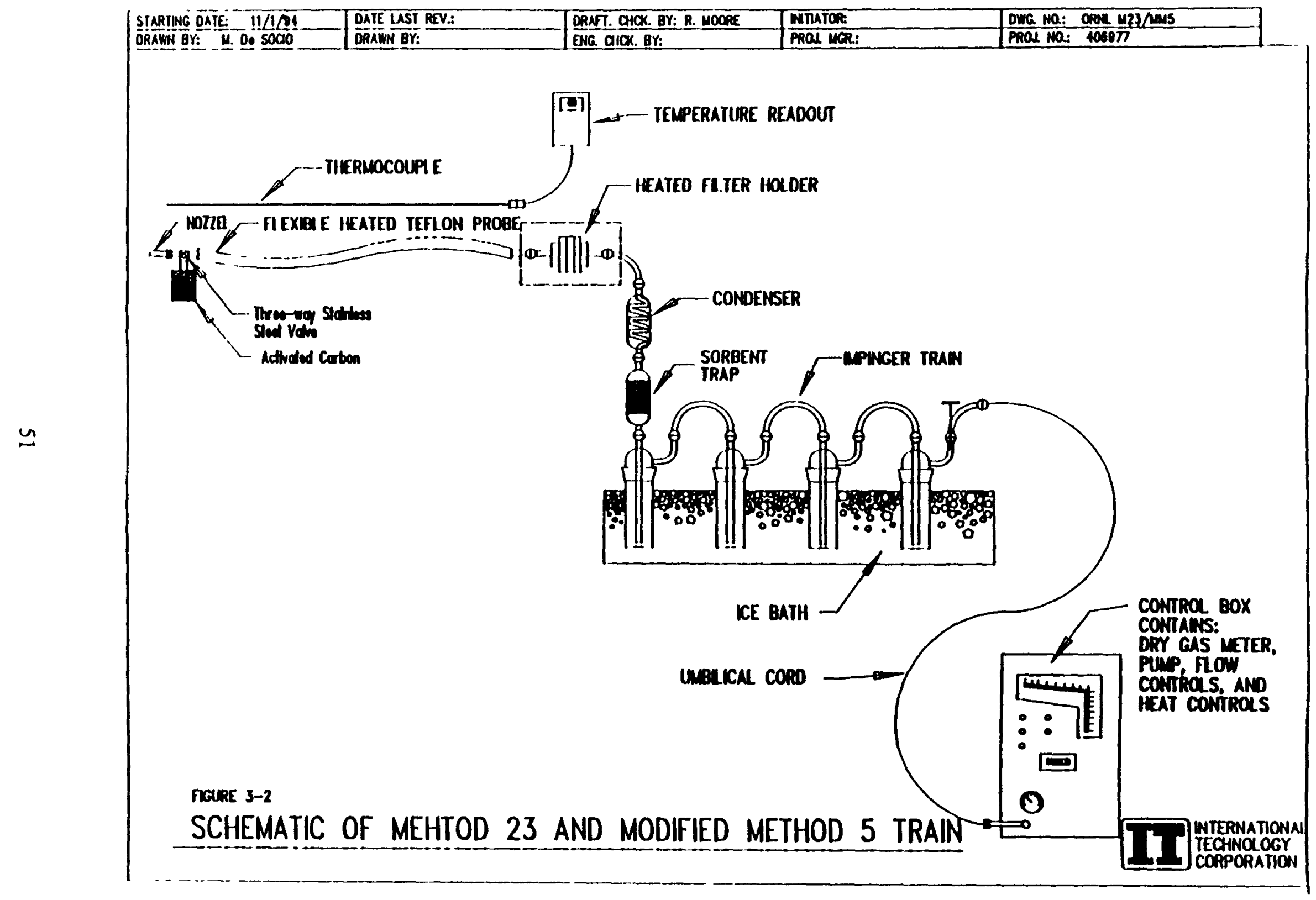




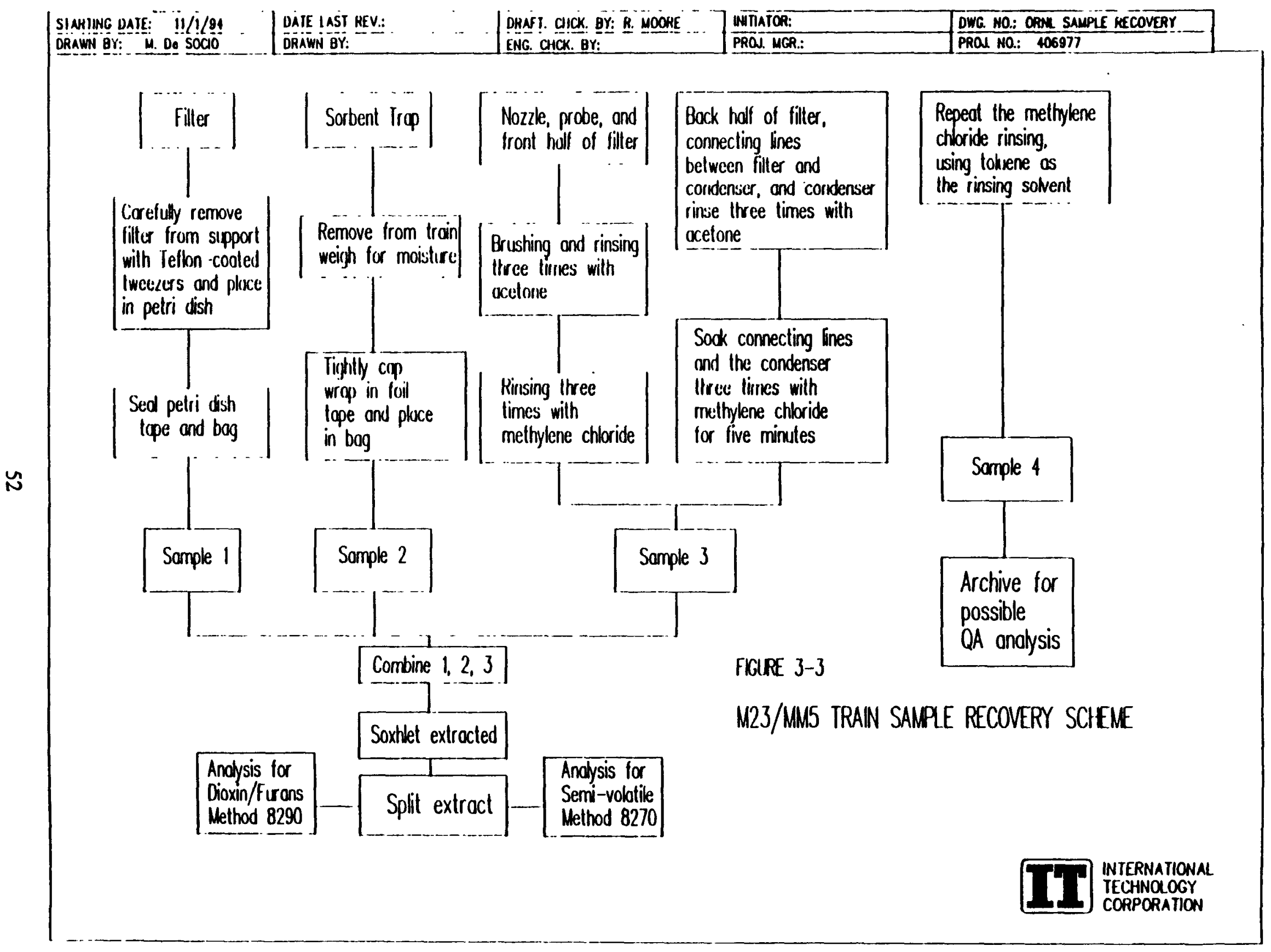




\subsection{Equipment Callbration Overviow}

Proper equipment calibration is essential in maintaining the desired data quality level. All calibrations of the equipment used in the sampling portion of the test conformed to the guidelines outlined in the EPA quality assurance handbook, Quality Assurance Handbook for Air Pollution Measurement Systems, Volume III, Stationary Source Specific Methods (EPA-600/4-77-027a). The following sections give a synopsis of the calibration procedures for the main components of the sampling systems.

\subsection{Callbration Procedures}

\subsubsection{Dry Gas Moters/Orifico Moters}

The dry gas meters and orifice meters in each control box used during the test were calibrated in order to ensure accurate measurements of the sample gas volumes. The dry gas meters and orifice meters are normally housed as a set inside each control box and were calibrated as such. These sets of meters were calibrated against a primary calibration standard, a spirometer.

The dry gas meter/orifice meter sets were calibrated at different nominal volume flow settings. For each of these flow rates, a calibration coefficient $\left(Y_{V}\right)$ was computed for the individual dry gas meters. A successiul calibration for a particular dry gas meter would be achieved if each value of $Y_{i}$ were within 2 percent of the average value of $Y_{i}\left(Y_{i}=Y \pm 0.02 Y\right)$. All dry gas meters used during the tests met the acceptance criteria.

In order to establish calibration for the orifice meter, a orifice differential pressure coefficient ( $\triangle H @$ @) was also calculated for each flow rate. This coefficient is the orifice pressure differential (in inches $\mathrm{H}_{2} \mathrm{O}$ ) at a distinct orifice manometer setting that gives a flow of $0.75 \mathrm{ft} / \mathrm{min}$ of air at standard conditions. The desired tolerance for this coefficient is \pm 0.2 of the average value of the four values of $\Delta H @(\Delta H @ \pm 0.2)$. All orifice meters utilized during the test met the acceptance criteria.

- If any of the pre-test calibration coefficients for a parricular meter had violated the acceptance criteria. the meter in question would be adjusted and recalibrated. 


\subsubsection{Thermocouples and Thermocouple Readouts}

All thermocouples used during the tests were calibrated to ensure accurate temperature measurements. All of the sensors utilized were type " $\mathrm{K}$ " thermocouples, which have a working range of approximately $-300^{\circ} \mathrm{F}$ to approximately $2500^{\circ} \mathrm{F}$. These sensors were used in the measurement of gas temperature, probe sheath temperature, filter box temperature, and impinger temperature. The thermocouples were calibrated against an NBS traceable mercury-in-glass thermometer at three separate temperatures $(34,212$, and 350 degrees F). In order to obtain the calibration data from each sensor, a single, recently calibrated thermocouple readout was used. The calibrations indicated that all sensors met the most stringent acceptance limitations for any of the temperaure measurements previously mentioned without any adjustment (per EPA guidelines).

The thermocouple readouts used during the tests were calibrated using a thermocouple simulator (Omega Model CL-300). This calibration apparatus generates a voltage signal which mimics the signal an ideal " $\mathrm{K}$ " type thermocouple would exhibit at a paricular temperature. The signal can be changed via a slide switch. The readouts were calibrated at ten different points from $200^{\circ} \mathrm{F}$ through $2000^{\circ} \mathrm{F}$, at increments of $200{ }^{\circ} \mathrm{F}$. None of the devices calibrated showed any deviation outside the most resurictive tolerance window thus making any adjustment unnecessary. 


\subsection{Results}

\subsection{Flow Rate and Gas Composition Results}

It is important to first nore that the flow rate and gas composition of the MSO unit were not detemined through standard testing methods as listed in CFR 40 part 60 . The standard testing methods were not utilized on this particular unit due to its unique design and access limitations. Flow rates and gas composition were determined through calculations using known variables such as feed rates, inlet and outlet temperatures, and composition of the feed material. The flow rate was determined using Ideal Gas Laws and Conservation of Mass. Gas composition was based on the complete combustion of the feed material and measured inlet volumetric flow rate. The calculations used for the determining the exhaust flow rate and gas composition are located in Attachment F.

Using the field data collected during the VOST test, the sample volume was converted to dry standard conditions (see Attachment E). It was then used to calculate the emission rate for the volatile organic compounds that were anaiyses in each test (see Attachment B).

The exhaust flow rate used in the calculation was determined from the M23/MM5 results.

Using the field data collected during the M23/MM5 the sample volume and exhaust flow rate were converted to dry standard conditions (see Attachment $E$ ). They were then used to calculate the emission rate for the dioxins. furans and semi-volatile compounds that were analyzed in each test (see Attacinment D).

\subsection{Volatile Organic Compounds Results}

Listed in Table 5-1 are sixteen volatile compounds from the hazardous substance list that were detected and three tentativeiy identified compounds. The analytical quantification limit was 10 nanograms for compounds listed from chloromethane through $\mathrm{m} / \mathrm{p}$-xylene, and 20 nanograms for the remainder. yielding an approximate detection limit in the exhaust of $.46 \mathrm{ug} / \mathrm{m}^{3}$ and $.87 \mathrm{ug} / \mathrm{m}^{3}$ respectively.

Any result that is preceded by a "<" sign signifies that the compound was not detected in at least one of the vost tubes for that particular test. To determine the total average for the test, the 
Volatue Organic Emission Resutts

(ug/hr)

$\begin{array}{llllll}\text { Test: } 1 & \text { Tes: } 2 & \text { Test: } 3 & \text { Test } 5 & \text { Test: } 6 & \text { Test } 7\end{array}$

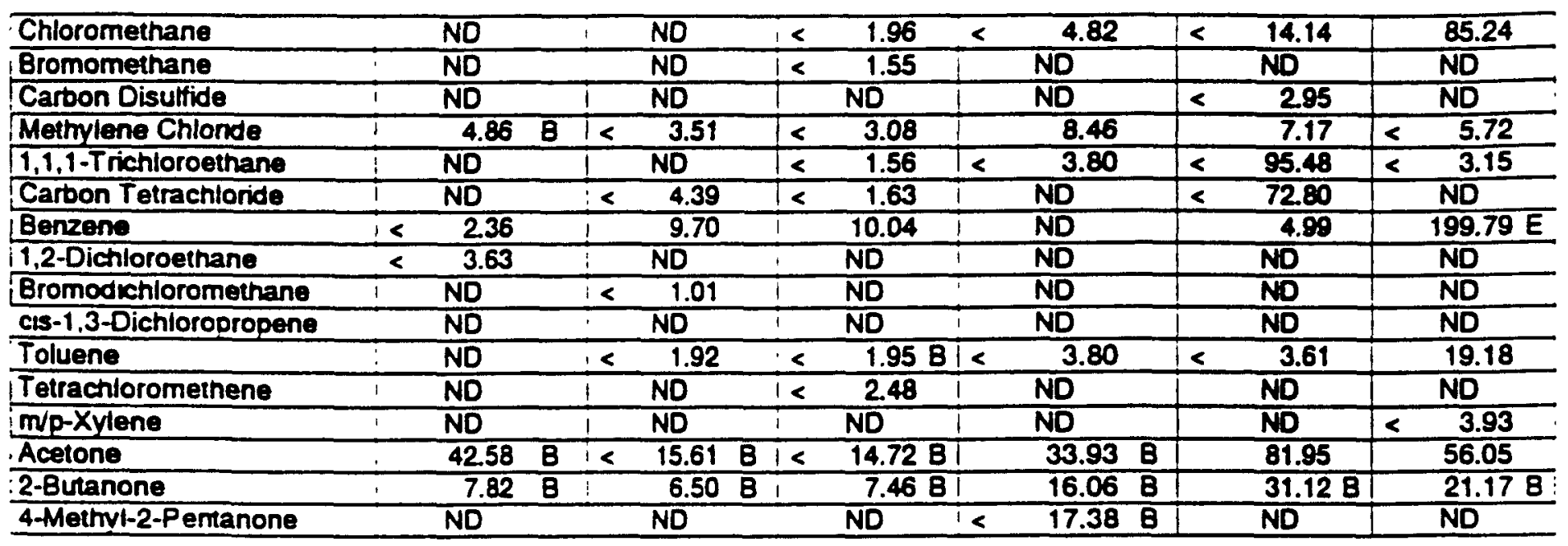

Volatule Organic Emission Results (TICs)

(ug/hr)

\begin{tabular}{lcccccccc}
\hline Heptane & 3.30 & $\mathrm{~J}$ & 1.52 & $\mathrm{~J}$ & $3.18 \mathrm{~J}$ & $12.24 \mathrm{~J}$ & $52.46 \mathrm{~J}$ & $12.09 \mathrm{~J}$ \\
\hline Hexane.3-Ethvi & ND & 51.48 & $\mathrm{~J}$ & $3.18 \mathrm{~J}$ & 14.30 & $\mathrm{~J}$ & $2.84 \mathrm{~J}$ & $7.43 \mathrm{~J}$ \\
\hline Pentane, 3-Methvi & ND & ND & ND & 3.70 & ND & $3.29 \mathrm{~J}$ \\
\hline
\end{tabular}

A-Suspected ablol condensation product

B-Anatye was found in the blank as well as the sample

E-Compound exceeded calibration range of instrument

$Y$-indistunguishable isomer in tentativen dentried compounds
$\mathrm{J}$-indiates an estimated value

ND-None detected

-Value outside of QC limits

$<-$ indicates detection limit was used in calculations 
detection limit was used. The results for all the volatile pollutants analyzed are included in Attachment B. The mass emission rates are reported in micrograms per hour and are based on the gas stream flow rate which was measured by the M23/MM5 trains for each run. Sample volumes, gas flow rates and isokinetic resuits can be found in Attachment E. The complete analytical resuits from the laboratory can be found in Attachment I.

\subsection{Modifled Mothod 5 Results}

Listed in Table 5-2 are eight semi-volatile compounds that were detected, followed by three tentatively identified compounds. The analytical quantification limits were 10 micrograms for the first three tests and 100 micrograms for the last three test for all compounds listed, yielding an approximate detection limit in the exhaust of $2.94 \mathrm{ug} / \mathrm{m}^{3}$ and $32.00 \mathrm{ug} / \mathrm{m}^{3}$. respectively.

The results for all the semi-volatile pollutants analyzed are included in Attachment $D$. The mass emission rates are repored in micrograms per hour and are based on the gas stream flow rate measured by the M23/MMS trains for each run. Sample volumes, gas flow rates and isokinetic results can be found in Attachment $E$. The complete analytical resuits from the laboratory can be found in Attachment I.

\subsubsection{Results from the Isokinetic Sampling}

Listed in Table 5-2a are the isokinetic results. The average stack temperature measured by the sampling train was $304^{\circ} \mathrm{F}$ and $488^{\circ} \mathrm{F}$ for tests $1-3$ and tests $5-7$ respecrively. The average sample volume was 122.11 and 110.53 standard cubic feet respectiveiy. Moisture content of the exhaust averaged 12.4 and 11.7 percent by volume respectively. The average stack gas velocity measured by the sampiing train was 364 and 902 feet per minute respectively. The average volumetric flow rate was 1.847 and 3.700 at dscfm, respectively. The average isokinetic sampling was 100 and 98 percent respectiveiy, with the high of 101 and a low of 95 percent. All Isolinetic sampling information can be found in Attachment $E$.

\subsection{Dloxins and Furans Results}

Listed in Table 5-3 are dioxins, furans and their isomers that were detected. The mass emission rares are repored in picagrams per hour. Sample volumes, gas flow rates and isokinetic results

- can be found in Attachment $E$. The complete analytical data packages from the laboratory can be found in Atrachment I. 


\section{Martin Mariatta Energy Systems}

Results Tabie 5-2

$12 / 10 / 94$

Semivolatıle Organic Emission Results

(ughr)

$\begin{array}{llllll}\text { Test: } 1 & \text { Test: } 2 & \text { Test: } 3 & \text { Test: } 5 & \text { Test/ } 6 & \text { Test: } 7\end{array}$

\begin{tabular}{|c|c|c|c|c|c|c|c|c|}
\hline Benzyl Alconol & 53.16 & $\bar{B}$ & & $4.22 \mathrm{BJ}$ & $1.08 \mathrm{BJ}$ & $64.33 \mathrm{BJ}$ & ND & ND \\
\hline 2-Mothylphenol & 4.98 & J & 1 & ND & ND & $42.89 \mathrm{BJ}$ & ND & ND \\
\hline 4-Methylphenol & 4.15 & $\mathrm{~J}$ & 1 & ND & ND & $42.89 \mathrm{BJ}$ & $\overline{N D}$ & ND \\
\hline Nitrobenzene & 1.66 & $\mathrm{~J}$ & T & ND & ND & ND & ND & $\overline{\text { ND }}$ \\
\hline Di-nbutylphthalate & 0.83 & $\mathrm{~J}$ & 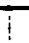 & ND & $2.17 \mathrm{~J}$ & ND & ND & ND \\
\hline Chrysene & NO & & 1 & $4.22 \mathrm{BU} !$ & ND & ND & ND & ND \\
\hline Bis (2-Ethylhexyl) Phthalate & 11.63 & $\bar{B}$ & $t$ & $0.84 \mathrm{~J}:$ & $36.87 \mathrm{~B}$ & $60.04 \mathrm{BJ}$ & 28.78 Bd & $21.72 \mathrm{BJ}$ \\
\hline Di-n-Octyl Phthalate & 9.97 & & 1 & ND & ND & ND & ND & ND \\
\hline
\end{tabular}

Semivolatile Organic Emission Results (TICs)

(ug/hr)

\begin{tabular}{|c|c|c|c|c|c|c|c|}
\hline Benzaldehyde & $191.05 \mathrm{ABJ}$ & $2.87 \mathrm{BJ}$ & ND & 1 & $143.67 \mathrm{BJ}$ & ND & ND \\
\hline Benzene, (Methvl-Propervil) & $2.74 \mathrm{JY}$ & ND & ND & $\mathrm{i}$ & NO & ND & ND \\
\hline 3-Buten-2-One.4-Phervil & ND & ND & ND & & $107.22 \mathrm{~J}$ & ND & ND \\
\hline
\end{tabular}

A-Suspected aldol condensation product

B-Analyte was found in the btank as well as the sample E-Compound exceeded calibration range of instrumem

$Y$-Indistinguishable isomer in tentativen identfied compounds
$J$-Indiates an estimated value

ND-None detected

-Value outside of QC limits 
Martin Marietra Energy Systems

Results Table 5-2a

Isokinetic Sampling Results

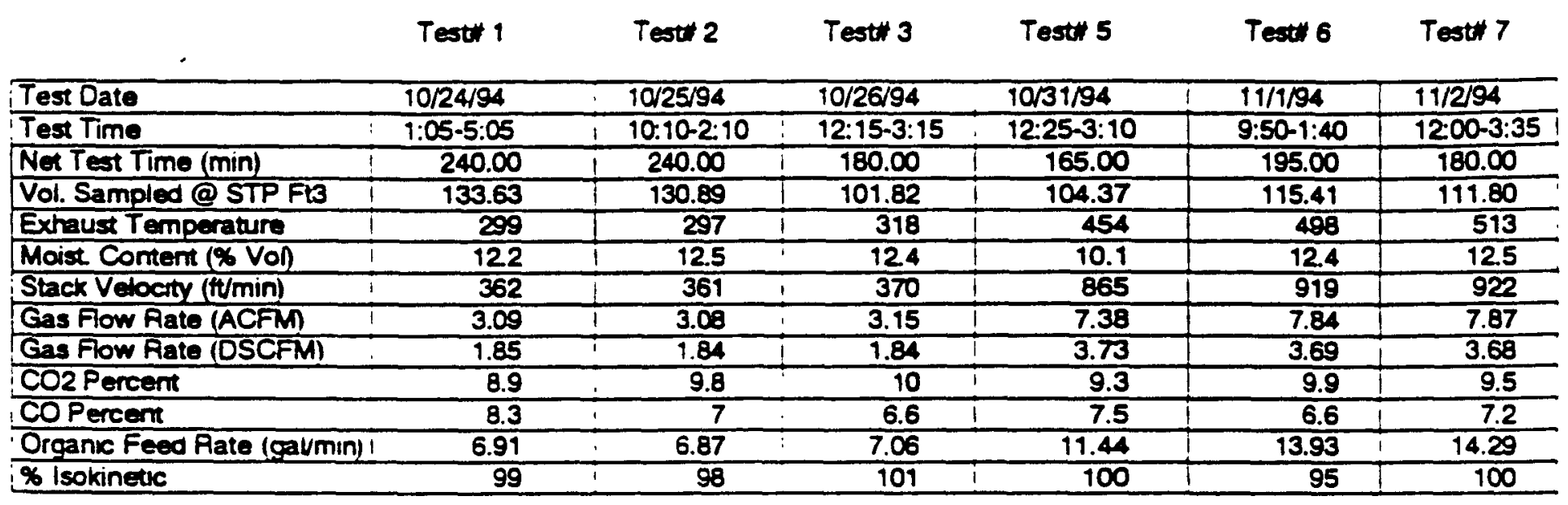




\section{Martin Mariotta Enorgy Systems \\ Results Table 5-3}

$12 / 10 / 94$

Dioxins \& Furans Emission Resutts

(pg/hr)

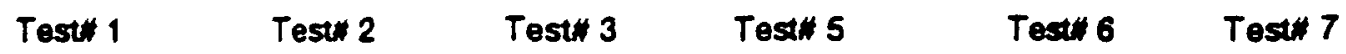

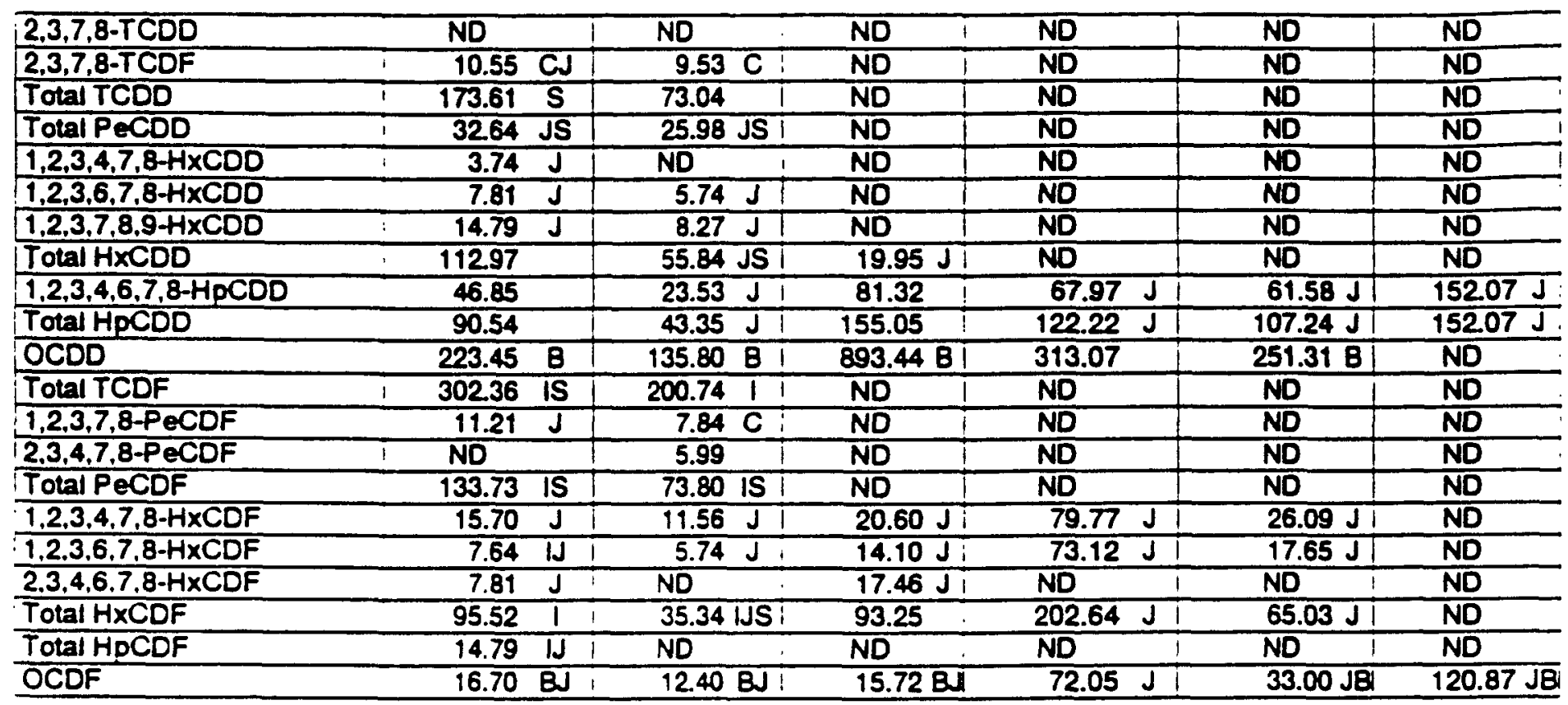

C-Co-eluting isomer present

B-Anatyte was found in the blank as well as the sample

E-Compound exceeded calibration range of instrumem I-Possible Polychionnated Diphenyl ether interference
$J$-Indiates an estimated value

NO-None detected

S-Possible ion suppression indicated by PFK mass Intensity 


\subsection{Destruction/Removal Efflciency (DRE)}

Table 5-4 lists the Destruction/Removal Efficiencies (DREs) that were achievable from the analytical results. The DRE must be 99.99 percent or better to conform to RCRA regulations. The DRE is determined by subtracting the hazardous material exiting the MSO unit from the hazardous material feed into the unit, then dividing by the hazardous material feed into the unit and multiplying by one hundred. It should also be noted that any of the number listed in Table 5-4 followed by an asterisk indicates that the calculation was solely based on detection limits. If lower detection limits were obtainable, higher numbers could be achievable.

\subsection{Total Toxicity Equivalent Concentrations}

Table 5-5 lists the total toxic equivalent factor for each test. All dioxins, furans and their isomers are expressed in units of 2,3,7,8-TCDD in picagrams. It appears that the first three tests had higher concentration levels of total toxicity, than the last three. However note that the results reported from the laboratory as total toxic equivalent concentrations do not include the detection limit for compounds that were not detectable. Tests 5-7 had higher detection limits, and since the equivalent calculation method omits non detected compounds the total equivalent concentration is lower. Comparing results from test 2 to 6 and test 3 to 7 would support this conclusion.

\subsection{Test* 4 Background Sample Concentratlons}

Table 5-6 list the semi-volatiles, dioxins and furans concentration levels that were detected in the lab background sample. A M23/MM5 tain was assembled in the lab next to the MSO unit and operated for 150 minutes. A total voiume sampie of 102.28 cubic feet at standard pressure and temperature was collected. During the sampling the MSO unit was not operated, so that only concentration levels of the semi-volatiles, dioxins and furans that are present in the room would be collected. 
Pesulle Table 5-4

IT PRONECTI 406977

Destruction Removal Efficlency

$12 / 1004$

\begin{tabular}{|c|c|c|c|c|c|c|c|c|}
\hline Compound & _ Test!n! & Teatu 2 & Testw 3 & & & & & Tosin $?$ \\
\hline Cartion Telractioride & 99098992 . & 09.899971 & 99.999980 & $>$ & 99.8998968 - & $>$ & 09.099763 & 09.899991 \\
\hline 1.1.1-Trichlorothane & 99.899992 . & 99.998900 - & 99.998990 & $\geq$ & 09.999905 & $\geq$ & 99.999686 & 09.899990 \\
\hline 2.4-Dichlorophenol & 99.899828 - & 99 9998808 - & 99.899930 : & $\geq$ & 09.090203 * & $>$ & Ma & 09.098734 \\
\hline
\end{tabular}

>- Indicates Ule use of a delecilon limlt

- Calculation based seluly on detucaton limile 


\begin{tabular}{|c|c|c|c|}
\hline & & $\begin{array}{c}\text { Total Toxic Equivalent } \\
(\mathrm{pg})\end{array}$ & $\begin{array}{c}\text { Concentration Level } \\
\left(\mathrm{pg} / \mathrm{m}^{3}\right)\end{array}$ \\
\hline Test 1 & | Sample \# 1342, 1343, 1344 & 9.7181 & 2.57 \\
\hline Test\# 2 & Sample \# 1351, 1352, 1353 & 9.3097 & 2.51 \\
\hline Test 3 & Sample \# 1359, 1361, 1362 & 6.3985 & $2.22 !$ \\
\hline Test\# 4 & Sample \# 1363, 1364, 1365 & 2.4208 & 0.64 \\
\hline Test 5 & Sample \# 1372, 1372, 1375 & 7.6266 & 2.63 \\
\hline Test\# 6 & Sample \# 1380, 1381, 1382 & 2.7492 & 0.93 \\
\hline Test 7 & Sample \# 1394, 1395, 1397 & 1.6432 & 0.50 \\
\hline Blanks & Sample \# 1390, 1392. 1393, 1398, 1399 & 0.8882 & 0.28 \\
\hline
\end{tabular}

Results supported by Attachment $G$ 
Semmolatile Organic Concentration Level

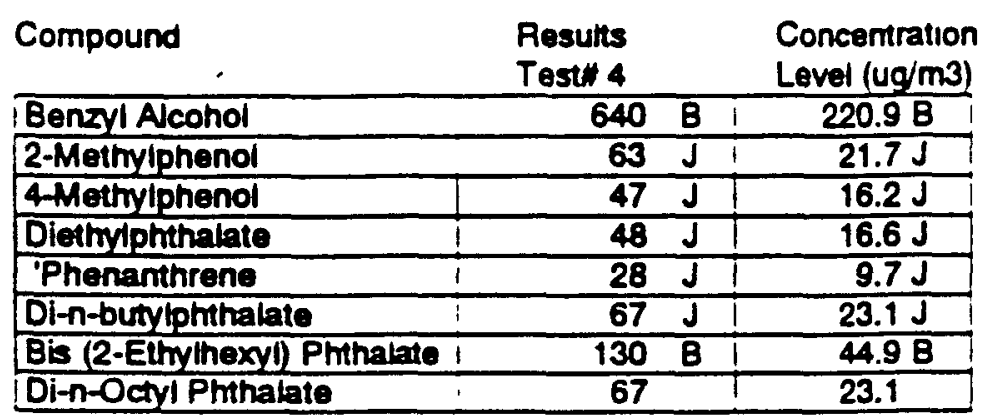

Semnotatile Organc Emission Resutts (TICs)

$$
\text { (ug/hr) }
$$

Benzaldenyde $\quad 1 \quad 16008 \mathrm{BJ} / 552.4 \mathrm{BJ}$

\section{C-Co-eluting isomer present}

B-Analyte was found in the blank as well as the sample E-Compound exceeded calubration range of instrumem 1-Possible Polychionnated Diphenyl ether imterference
Dioxins \& Furans Concentration Levels

\begin{tabular}{|c|c|c|}
\hline Compound & $\begin{array}{l}\text { Results } \\
\text { (pg) }\end{array}$ & $\begin{array}{c}\text { Concentration } \\
(\mathrm{pg} / \mathrm{m} 3)\end{array}$ \\
\hline 2,3.7,8-TCDO & ND & ND \\
\hline $7,8+4 \times C D D$ & $3.30 \mathrm{~J}$ & $1.14 \mathrm{~J}$ \\
\hline $\mathrm{H} \times \mathrm{CDO}$ & $5.90 \mathrm{~J}$ & $2.04 \mathrm{~J}$ \\
\hline Tot: & $33.40 \mathrm{~J}$ & $11.53 \mathrm{~J}$ \\
\hline $7,8+40 C 00$ & $25.20 \mathrm{~J}$ & $8.70 \mathrm{~J}$ \\
\hline Total HoCDD & $46.30 \mathrm{~J}$ & $15.98 \mathrm{~J}$ \\
\hline$\overline{O C}$ & $116.00 \mathrm{~B}$ & $40.05 \mathrm{~B}$ \\
\hline $7,8+4 \times C D F$ & $5.10 \mathrm{JS}$ & $1.76 \mathrm{JS}$ \\
\hline $1,2,3,6,7,8+4 \times C$ & $2.00 \mathrm{~J}$ & $0.69 \mathrm{~J}$ \\
\hline$\longdiv { 2 , 3 , 4 , 6 , 7 , 8 + H \times C D F }$ & $2.40 \mathrm{~J}$ & $0.83 \mathrm{~J}$ \\
\hline Total HXCDF & $16.80 \mathrm{JS}$ & $5.80 \mathrm{JS}$ \\
\hline$\overline{D F}$ & $14.5 \mathrm{JX}$ & $5.01 \mathrm{JX}$ \\
\hline & $14.50 \mathrm{JX}$ & $5.01 \mathrm{JX}$ \\
\hline OCD & $37.80 \mathrm{BX}$ & $13.05 \mathrm{BX}$ \\
\hline
\end{tabular}

$\mathrm{J}$-Indiates an estimated value ND-None detected S-Possible ion suppression indicated by PFK mass imtensity $X$-Defined separatly (see Case Narrative) 


\section{INTERNAL DISTRIBUTION}

$\begin{aligned} \text { 1. } & \text { E. C. Beahm } \\ 2 . & \text { J. M. Begovich } \\ 3 . & \text { J. B. Berry } \\ 4 . & \text { C. H. Byers } \\ \text { 5. } & \text { C. L. Calhoun, Jr. } \\ 6 . & \text { E. D. Collins } \\ 7 . & \text { A. G. Croff } \\ \text { 8-12. } & \text { S. M. Crosley } \\ 13 . & \text { S. Dai } \\ 14 . & \text { G. Del Cul } \\ 15 . & \text { L. D. Duncan } \\ 16 . & \text { B. Z. Egan } \\ \text { 17. } & \text { C. W. Forsberg } \\ \text { 18. } & \text { U. Gat }\end{aligned}$

\author{
19. D. L. Lennon \\ 20. S. A. Meacham \\ 21. L. E. McNeese \\ 22. R. E. Norman \\ 23. L. E. Nulf \\ 24. S. M. Robinson \\ 25-34. J. C. Rudolph \\ 35. Central Research Library \\ 36. ORNL-Y-12 Technical Library \\ Document Reference Section \\ 37-38. ORNL Laboratory Records \\ 39. ORNL Laboratory Records, RC \\ 40. ORNL Patent Section
}

EXTERNAL DISTRIBUTION

41. Office of Assistant Manager for Energy Research and Development, DOE-ORO, P.O. Box 2001, Oak Ridge, Tennessee 37831

42-43. Office of Scientific and Technical Information, P.O. Box 2001, Oak Ridge, Tennessee 37831

44. M. G. Adamson, Lawrence Livermore National Laboratory, P.O. Box 2008, Livermore, California 94550

45. R. J. Ayen, Rust Federal Services, Clemson Technical Center, 100 Technology Drive, Anderson, South Carolina 29625

46. F. Bacha, College de France, Laboratoire de Physique Corpusculaire, 11 Place Marcelin Berthelot, 75231 Paris Cedex 05, France.

47. J. T. Bell, 137 Bowspirit Lane, Kingston, Tennessee 37763

48. G. W. Billings, Thermal Technologies, Inc., 1911 Airport Boulevard, Santa Rosa, California 95403

49. T. J. Carlson, Rust Geotech, Inc., P.O. Box 14000, Grand Junction, Colorado 81502-5504

50. J. P. Consaga, Naval Surface Warfare Center, Indian Head Division, 101 Strauss Avenue, Indian Head, Maryland 20640-5035

51. C. Cooley, Trevion II, U. S. Department of Energy, Washington, D.C. 20585

52. J. L. Cox, Pacific Northwest Laboratory, Battelle Boulevard, Richland, Washington 99352

53. K. Furukawa, Institute of Research and Development, Tokai University, 1117 Kitakaname, Hiratsuka, Kanagawa 259-12, Japan

54. R. L. Gay, Rockwell International, Canoga Park, California 91303

55. P. A. Haas, 1205 Chickering Way, Knoxville, Tennessee 37923

56. H. F. McDuffie, 102 Colby Road, Oak Ridge, Tennessee 37831

57. J. D. Navratil, Rust Federal Services, 1597 Cole Boulevard, Suite 350, Golden, Colorado 80401-3414

58. C. Newman, Rockwell International, Canoga Park, California 91303

59. M. P. Polet, Alberta Special Waste Management Corporation, 610, 10909 Jasper Avenue, Edmonton, Alberta, Canada T5J 3L9

60. C. H. Reece, Rust Remedial Services, Inc., Clemson Technical Center, 100 Technology Drive, Anderson, South Carolina 29625 
61. B. Roy, Scientific Ecology Group, 1560 Bear Creek Road, P.O. Box 2530, Oak Ridge, Tennessee 37830

62. R. A. Scott, U.S. Department of Energy, San Francisco Operations Office, 1301 Clay Street, Room $406 \mathrm{~N}$, Oakland, California 94612-5208

63. A. L. Stewart, Rockwell International, Canoga Park, California 91303

64. W. Schwinkendorf, BDM Federal, 1801 Randolph Road SE, Albuquerque, New Mexico 87106

65. L. Taylor, U.S. Department of Energy, EM-43, 12800 Middlebrook Road, Germantown, Maryland 20874

66. D. W. Tedder, School of Chemical Engineering, 778 Atlantic Drive, Georgia Institute of Technology, Atlanta, Georgia 30332-0100

67. R. S. Upadhye, Lawrence Livermore National Laboratory, P.O. Box 2008, Livermore, California 94550

68. E. von Holtz, Lawrence Livermore National Laboratory, P.O. Box 2008, L-716, Livermore, California 94550

69. B. E. Watkins, Lawrence Livermore National Laboratory, P.O. Box 2008, Livermore, California 94550

70. M. H. West, Los Alamos National Laboratory, NMT-3, MS-E511, Los Alamos, New Mexico 87545

71. W. Yates, Naval Surface Warfare Center, Indian Head Division, 101 Strauss Avenue, Indian Head, Maryland 20640-5035

72. E. L. Youngblood, 198 North Purdue Avenue, Apartment 103, Oak Ridge, Tennessee 37830 